US Army Corps

of Engineers $S_{\circledast}$

Engineer Research and

Development Center

ERDC Technology Transfer and Infusion/Knowledge Management

\title{
Discover ERDC Support Staff User's Guide
}

Byron M. Garton, Jonathan S. Broderick,

September 2020

and Michael A. Clement 
The U.S. Army Engineer Research and Development Center (ERDC) solves the nation's toughest engineering and environmental challenges. ERDC develops innovative solutions in civil and military engineering, geospatial sciences, water resources, and environmental sciences for the Army, the Department of Defense, civilian agencies, and our nation's public good. Find out more at www.erdc.usace.army.mil.

To search for other technical reports published by ERDC, visit the ERDC online library at http://acwc.sdp.sirsi.net/client/default. 


\section{Discover ERDC Support Staff User's Guide}

Byron M. Garton, Jonathan S. Broderick, and Michael A. Clement

Information Technology Laboratory

U.S. Army Engineer Research and Development Center

3909 Halls Ferry Road

Vicksburg, MS 39180-6199

Final report

Approved for public release; distribution is unlimited.

Prepared for ERDC Office of Research and Technology Transfer (ORTT) 3909 Halls Ferry Road

Vicksburg, MS 39180-6199

Under ERDC Office of Research and Technology Transfer, WIC 19F1H5 


\section{Abstract}

Knowledge management plays a vital role for the successful execution of research projects at the U.S. Army Engineer Research and Development Center (ERDC). Accumulating and building upon knowledge is the cornerstone of the research and development process. Maintaining knowledge and providing access to it is essential to the successful execution of research programs. An initiative to improve access to knowledge and tools available to researchers was begun by the Office of Research and Technology Transfer (ORRT). The result of that initiative is a knowledge portal called Discover ERDC.

This document provides a detailed look into how content on the Discover ERDC site is maintained from a Support Staff viewpoint, and how those assigned to manage user accounts can accomplish their duties.

DISCLAIMER: The contents of this report are not to be used for advertising, publication, or promotional purposes. Citation of trade names does not constitute an official endorsement or approval of the use of such commercial products. All product names and trademarks cited are the property of their respective owners. The findings of this report are not to be construed as an official Department of the Army position unless so designated by other authorized documents. 


\section{Contents}

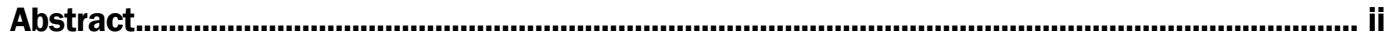

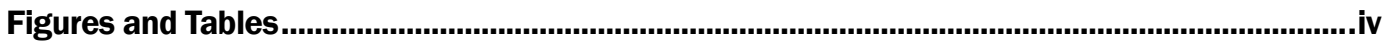

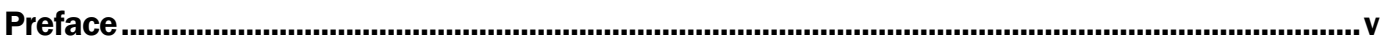

1 Introduction............................................................................................................................. 1

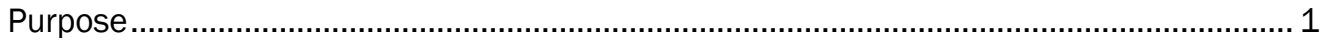

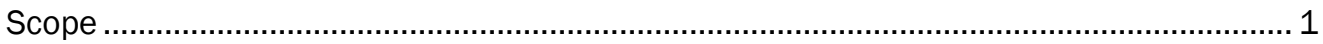

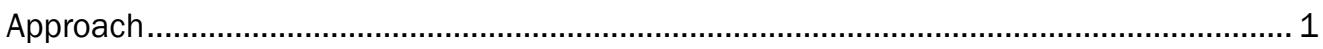

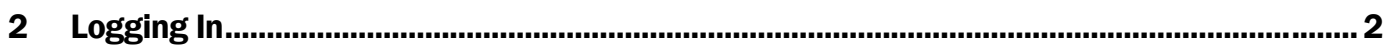

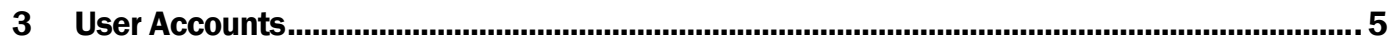

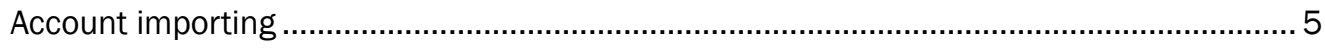

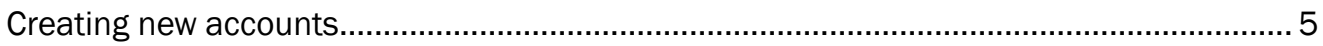

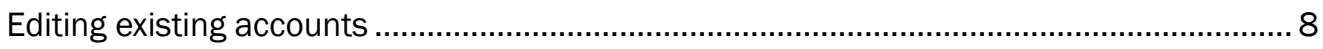

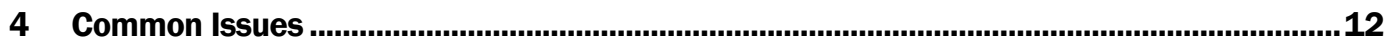

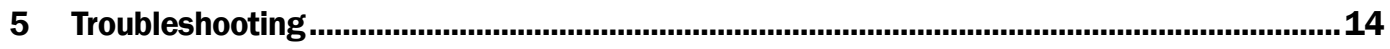

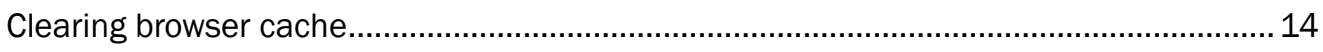

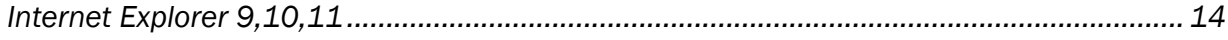

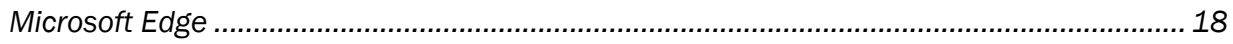

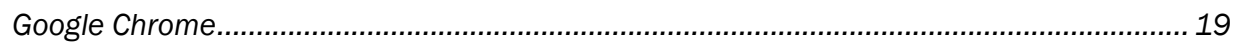

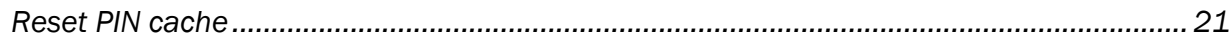

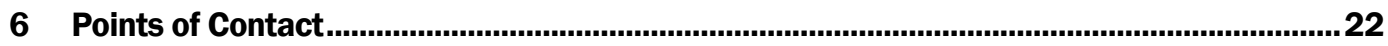

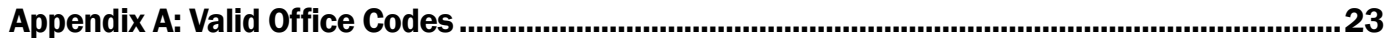

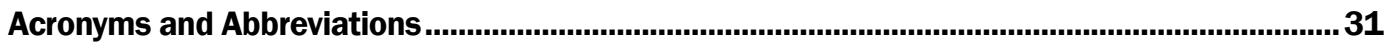

Report Documentation Page 


\section{Figures and Tables}

\section{Figures}

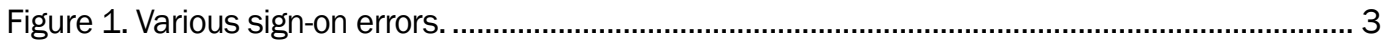

Figure 2. Standard DoD consent screen seen when visiting the site. ............................................... 3

Figure 3. Menu bar items. ........................................................................................................ 4

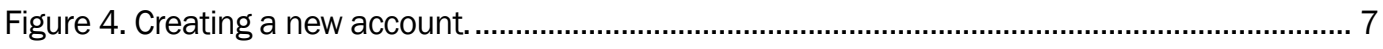

Figure 5. Discover Employees menu link.................................................................................. 9

Figure 6. View full profile for an employee from the employee search. ……...................................... 9

Figure 7. Edit a user's profile from the full profile view. .............................................................. 10

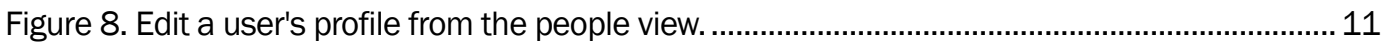

Figure 9. Certificate prompt in Google Chrome......................................................................... 12

Figure 10. Certificate selection in Internet Explorer.................................................................... 13

Figure 11. Single sign on errors. ....................................................................................... 14

Figure 12. Internet Explorer, step 1................................................................................... 15

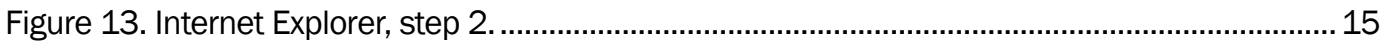

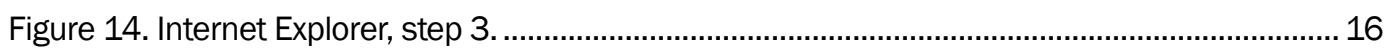

Figure 15. Internet Explorer developer tools, step 1.............................................................. 17

Figure 16. Internet Explorer developer tools, step 2 …............................................................ 17

Figure 17. Internet Explorer developer tools, step 3. ............................................................... 17

Figure 18. Microsoft Edge, step 1..................................................................................... 18

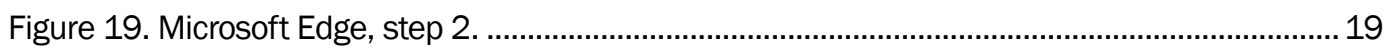

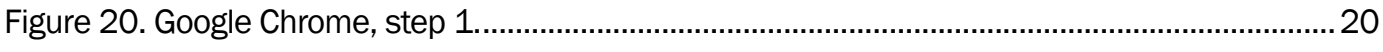

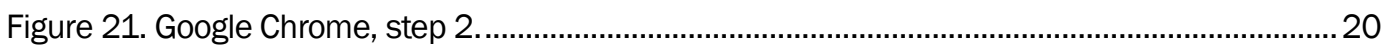

\section{Tables}

Table 1. Valid office codes. 


\section{Preface}

This research was conducted for the ERDC Office of Research and Technology Transfer (ORTT) utilizing Future Innovation Funds (FIF) for, "ERDC Technology Transfer and Infusion/Knowledge Management," by the ERDC Information Technology Laboratory. The technical monitor was Ms. Antisa C. Webb.

The work was performed by the Scientific Software Branch (SSB) of the Computational Science and Engineering Division (CSED), U.S. Army Engineer Research and Development Center - Information Technology Laboratory (ERDC-ITL). At the time of publication, Mr. Timothy W. Dunaway was Chief, SSB; and Dr. Jerrell R. Ballard, Jr. was Chief, CSED. The Deputy Director of ERDC-ITL was Ms. Patti S. Duett and the Director was Dr. David A. Horner.

COL Teresa A. Schlosser was the Commander of ERDC, and Dr. David W. Pittman was the Director. 


\section{Introduction}

\section{Purpose}

Knowledge management is an essential element to successfully executing research and development programs within the U.S. Army Engineer Research and Development Center (ERDC). Several iterations of knowledge management initiatives have been attempted over the years to address this vital role. From these initiatives, lessons were learned on the best ways to store and provide access to ERDC's vast knowledge base. From these lessons, several knowledge management products have been developed.

\section{Scope}

Discover ERDC is a multi-year effort to replace several outdated applications on the Research and Delopment Environment (RDE )with a single, modern-styled application, improving functionality and usability, and reducing the effort of system maintenance. The resulting application includes functions for searching and locating content on RDE, locating ERDC employees, identifying human capital metrics, and providing supervisory tools. All of these functions were previously handled by independent applications, but now they are all in one user-friendly location.

\section{Approach}

Discover ERDC is built on top of a content management system (CMS) that allows various users with assigned roles to maintain the site's accounts and content. Every employee at ERDC has a user account in the system, but only a few support staff are assigned roles to maintain the system. Knowledge Management Representatives (KMRs) are assigned specific parts of the site that are their responsibility to maintain, and they are only permitted to edit the content of those parts. Other support staff are assigned the role of maintaining the user accounts in the system. This guide focuses on the support staff duties of maintaining those user accounts. 


\section{Logging In}

Discover ERDC utilizes ERDC's single sign on (SSO) system on the RDE network. The CMS automatically logs in users who are authenticated via SSO. The benefit of using SSO for authentication is users will only have to log in once for any systems that also use SSO, which will eliminate having to use their common access card (CAC) multiple times. SSO is used on Discover ERDC and the ERDC Wikis, so traversing between those systems is seamless. Another benefit is users are not required to remember any user names or passwords since only a CAC and associated PIN are required.

Discover ERDC is housed on the external RDE network, but restricted to the .mil IP range. What that means to users is the site is accessible from both the U.S. Army Corps of Engineers-Information Technology (ACE-IT) and RDE networks, as well as from all other Department of Defense (DoD) networks.

To log in to the site, first open a web browser and point it to https://discover.erdc.dren.mil. Chrome, Safari, and Edge tend to work best, but Internet Explorer is also supported. A prompt will appear to choose a certificate from your CAC. Make sure to always choose the EMAIL certificate, if the wrong certificate is chosen, there are additional steps in the Common Issues section that will have to be completed to get back to a certificate prompt. Next, enter your CAC PIN when requested, which should lead to the consent screen as seen in Figure 2.

Although rare, sign-on errors can occur. If any of the error screens shown in Figure 1 are received, please review the Common Issues section for steps to fix the majority of sign-on errors. 
Figure 1. Various sign-on errors.

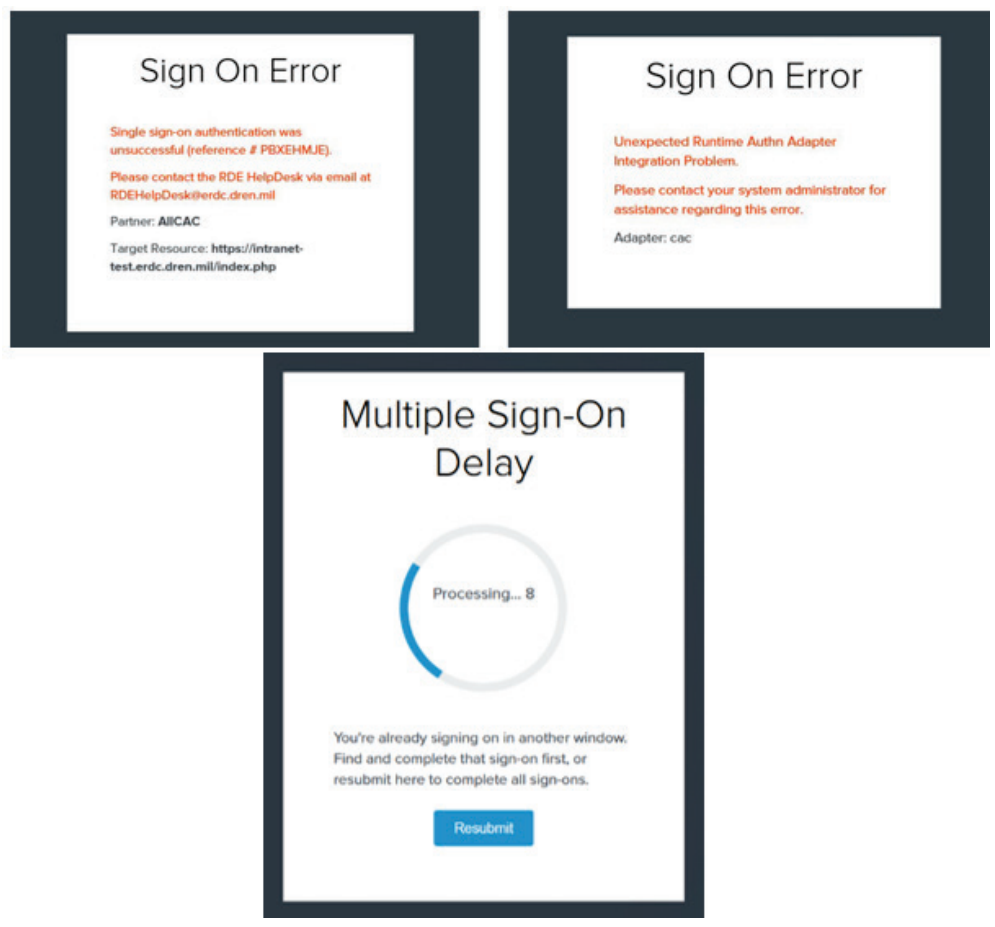

Figure 2. Standard DoD consent screen seen when visiting the site.

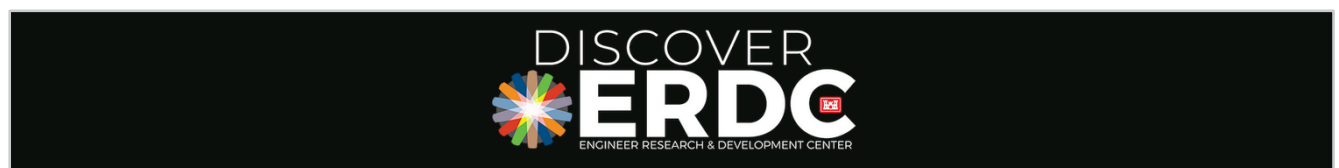

YOU ARE ACCESSING A U.S. GOVERNMENT (USG) INFORMATION SYSTEM (IS) THAT IS PROVIDED FOR USG-AUTHORIZED USE ONLY.

By using this IS (which includes any device attached to this IS), you consent to the following conditions:

- The USG routinely intercepts and monitors communications on this IS for purposes including, but not limited to, penetration testing, COMSEC monitoring network operations and defense, personnel misconduct (PM), law enforcement (LE), and counterintelligence (CI) investigations.

- At any time, the USG may inspect and seize data stored on this IS.

- Communications using, or data stored on, this IS are not private, are subject to routine monitoring, interception, and search, and may be disclosed or used for any USG-authorized purpose.

- This IS includes security measures (e.g., authentication and access controls) to protect USG interests.

- Notwithstanding the above, using this IS does not constitute consent to PM, LE or Cl investigative searching or monitoring of the content of privileged communications, or work product, related to personal representation or services by attorneys, psychotherapists, or clergy, and their assistants. Such communications and work product are private and confidential.

- Agreement to the Privacy Policy.

- Agreement to the Acceptable Use Policy. 
Once in, click the I Agree button, which will be redirect the user to the Discover ERDC landing page.

As mentioned previously, all support staff have assigned user account management roles, and a black bar will appear at the top of the page after successful $\log$ in. The support staff functions in this bar are enumerated below Figure 3 .

Figure 3. Menu bar items.

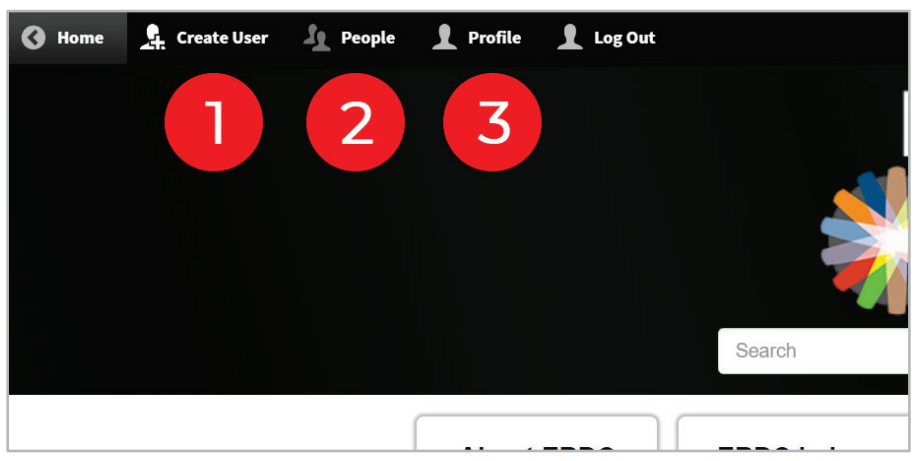

1. Create User - Create a new user in the system.

2. People - Find an existing user in the system.

3. Profile - View your individual profile. 


\section{User Accounts}

Every ERDC employee should have an account in Discover ERDC. Most employees were imported from the ERDC Active Directory when the Discover ERDC project first started, but since that time, many employees' statuses have changed. These situations require user account maintenance, which is handled by those assigned the support staff role.

\section{Account importing}

Discover ERDC periodically imports accounts from the ERDC Process Automation System (E-PAS) for federal employees. Accounts for contractors are a bit different, which is described in the next section. Federal employees should first get an account with E-PAS, which will send their information to Discover ERDC after an automated sync with the E-PAS database. No interaction from the support staff is required for this to occur. The user should be made aware that there may be a short delay between updates. Currently, the automated sync occurs weekly, but may be increased to daily in the future. If the user requires immediate access, follow the instructions for contractor accounts in the next section. For assistance with creating an E-PAS account, visit their website at https://myepas.erdc.dren.mil/. Account creation is fairly automated and should require limited input.

\section{Creating new accounts}

The majority of accounts are automatically imported into the system, but contractor accounts are a little trickier. Before creating a new account on Discover ERDC, there are a few points to consider.

First, accessing Discover ERDC requires the user to (at a minimum) have an RDE Application Account (RDE PUB). An application account is requested by the user completing the condensed version of Form DD2875. The condensed form is only one page and eliminates several fields from the full DD2875 that are not required. An RDE application account allows the user to have a record in RDE Public Active Directory (Pub AD). Several RDE hosted applications, including Discover ERDC and E-PAS, rely on Pub AD for authentication. An application account in Pub AD is required for all employees, regardless of employment type, to be authenticated by the system. This process requires the RDE Help Desk to process the form 
and create the appropriate RDE account. This process must be complete before creating an account in Discover ERDC.

Second, identify the type of user requesting an account. Is the user a federal employee or a contractor? Accounts for contractors are not automatically imported into Discover ERDC from E-PAS the way federal employees are, so they will require manual creation. A support staff employee with the proper roles defined in Discover ERDC can enter the new account information. The ERDC Office of Research and Technology Transfer (ORTT) coordinates with the Discover ERDC developers to determine who will be assigned the support staff role. The ORTT then communicates who is assigned as support staff to the various labs and offices. More than one person can be given this role, but typically only one person per lab or office is assigned the support staff role. See the Points of Contact section later in this document for contact information.

To create a new account for a contractor, use the Create User button at the top left of the screen as seen in Figure 3. The new user screen has many fields that can be edited, but only a few are required to create an account. Contractor (check box), First and Last Name, Email Address, Authentication Email Address (must match email in PUB AD), Office Code, Job Title, Telephone Number, and EDIPI number (number on back of $\mathrm{CAC}$ ) are the only data points required. All this information should be provided by the user on Form DD2875. Once the required information has been gathered for the user, it may be entered in the boxes enumerated in Figure 4 . 
Figure 4. Creating a new account.

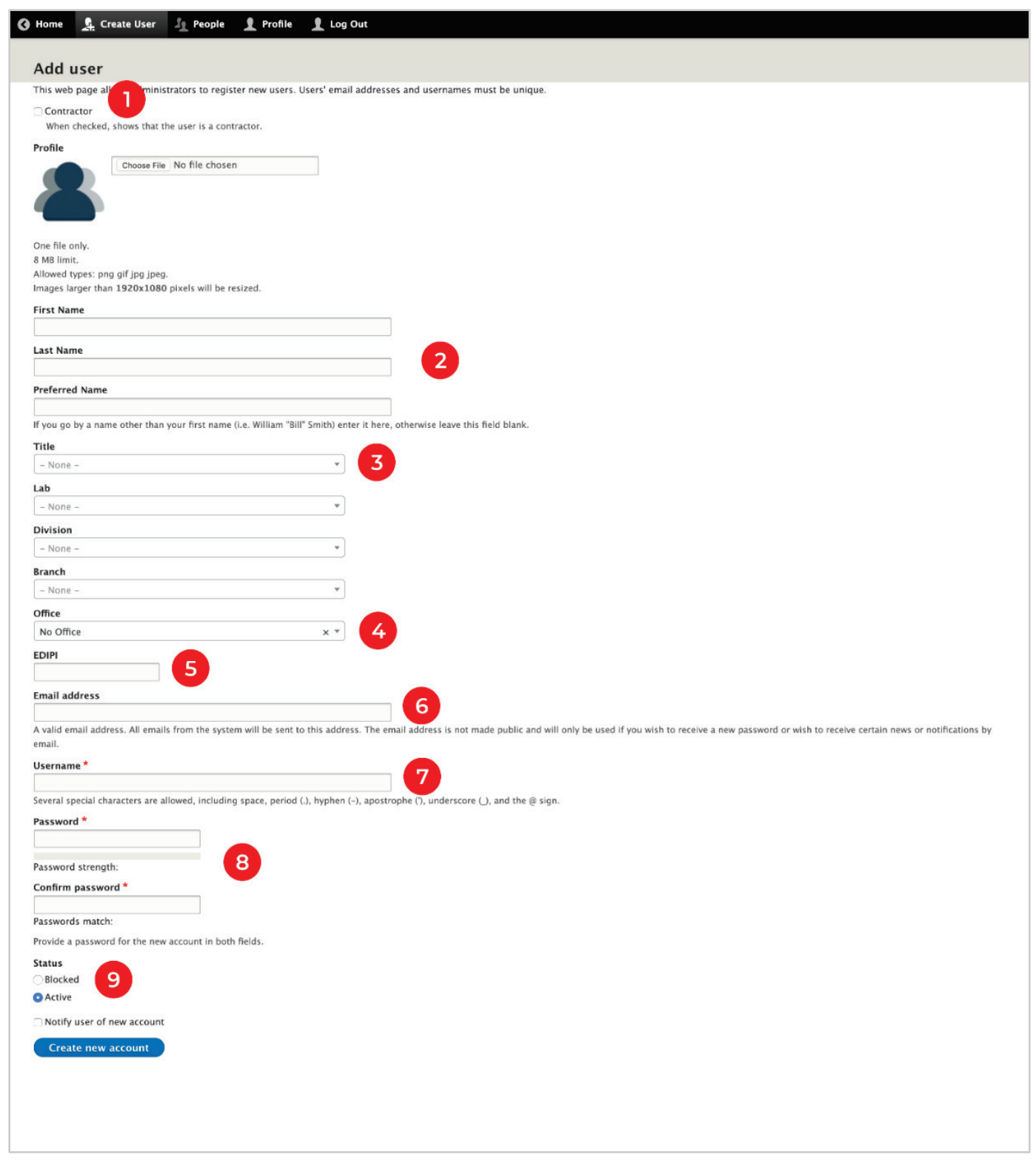

1. Contractor - Check this box if the new user is a contractor. If they are a federal employee, leave it unchecked.

2. First, Last, and Preferred Name - Enter the user's legal first and last name, not their preferred or nickname. You or the user can enter their preferred name later.

3. Title - Enter the user's official job title here. This field is set to autocomplete and will begin showing matching results when typing is initiated. Choose a result from the list, or continue to enter the job title if no matches are found. The new job title will be saved for future use. Please be careful with spelling and capitalization because these job titles appear 
on user profiles and are used to search and find users with certain expertise.

4. Office - Enter the user's official office code. These symbols change whenever organizational changes are made, so the list may periodically need to be updated. Refer to Table 1 for a current list of valid office codes. This field is set to autocomplete and will begin showing matching results when you begin typing. These codes are used internally for various functions and should always match a code in Table 1. Failure to choose the correct office code will result in categorization and search issues.

5. EDIPI - Enter the user's EDIPI number from their CAC. The user should have provided this when applying for a user account. Do not continue creating the user without this information.

6. Email Address - This should be the email address that is in RDE Pub $\mathrm{AD}$. The user may enter their preferred email address on their own if not the same as the Pub AD email.

7. Username - This field is used to authenticate the user. This should be the email address that is in $\mathrm{RDE}$ Pub $\mathrm{AD}$, not their personal or preferred email. Failure to enter the correct email address will result in the user being unable to log in to their account.

8. Password - This field is also used to authenticate the user, so it is very important to enter it correctly. The format for this field is EDIPI@mil. For example, if the user's EDIPI is 1234567890 , then enter 1234567890@mil in the box. Enter this value in the Confirm Password box below as well.

9. Status - A new user's status should be active, and this option is selected by default. If for some reason an inactive account needs to be created, change this option to blocked.

Once all information is entered and reviewed for correctness, click the create new account button to finish the process. There is no need to check the box to notify the user of new account. Now have the user attempt to $\log$ in to the account using their CAC and PIN by navigating to https://discover.erdc.dren.mil. Refer to the sections Common Issues and Troubleshooting in Chapters 4 and 5 if there are any issues logging in.

\section{Editing existing accounts}

The most common reason to edit an account would be updating authentication fields like EDIPI, username and password, or to disable the account temporarily or permanently. Accounts are never deleted from the system, only enabled or disabled. This needs to be done manually for contractors. Federal employees will get enabled and disabled 
automatically when syncing to E-PAS, which requires no support staff interaction. Another reason to edit a user account would be to change a user's office code, but remember, this would only be necessary for contractor accounts. Federal employee accounts should never be edited since they are updated automatically from E-PAS.

To find an employee account to edit, either use the Discover Employees search box or use the People button at the top left of the screen. A link to Discover Employees is in the home page menu as shown in Figure 5.

Figure 5. Discover Employees menu link.
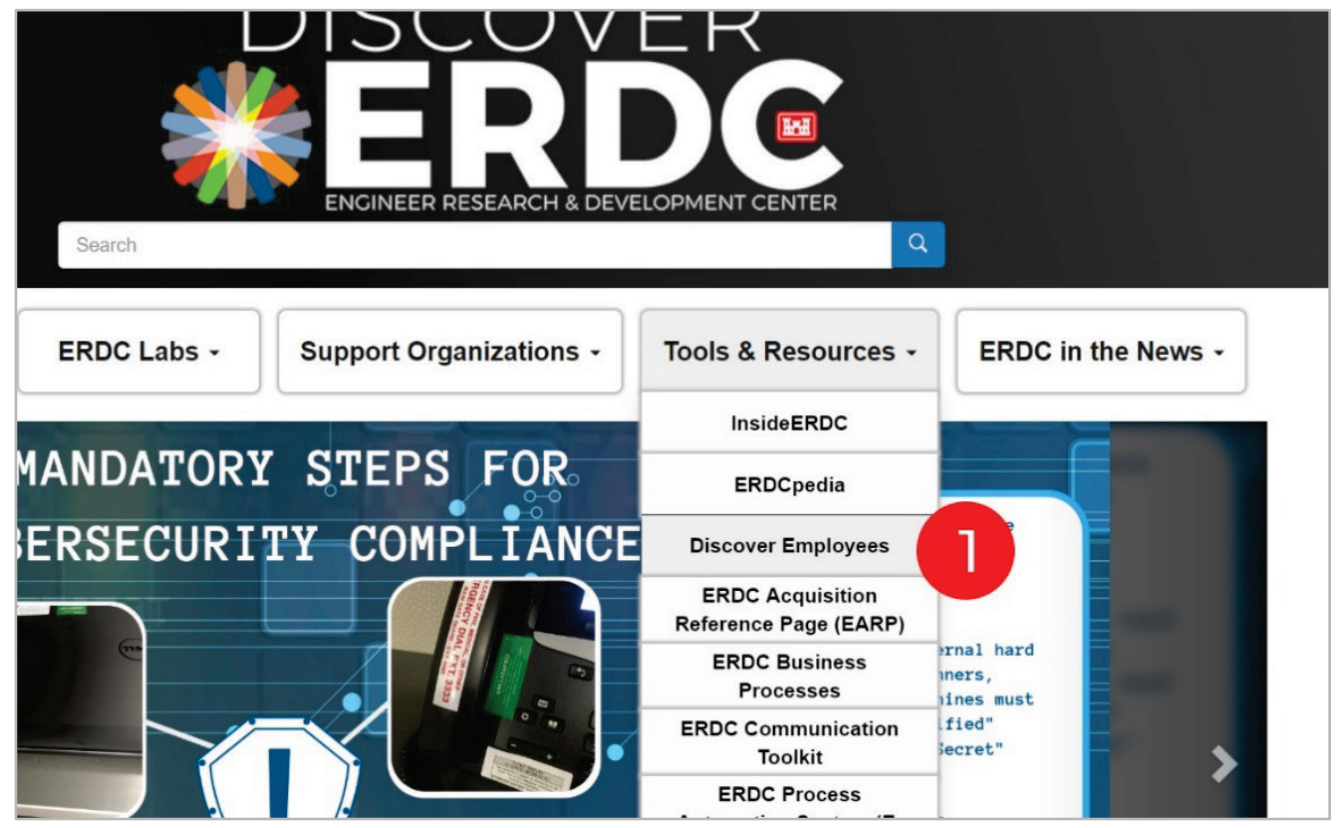

When using the Discover Employees search box to find and edit a user account, first click on View Full Profile in the search results list, then Edit Profile as shown in Figures 6 and 7.

Figure 6. View full profile for an employee from the employee search.

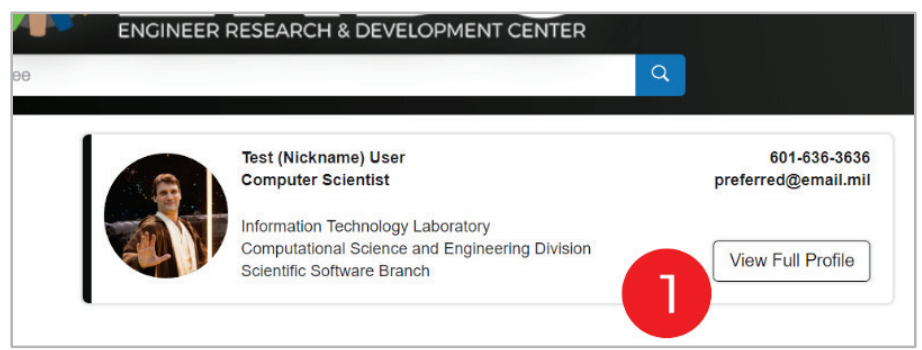


Figure 7. Edit a user's profile from the full profile view.

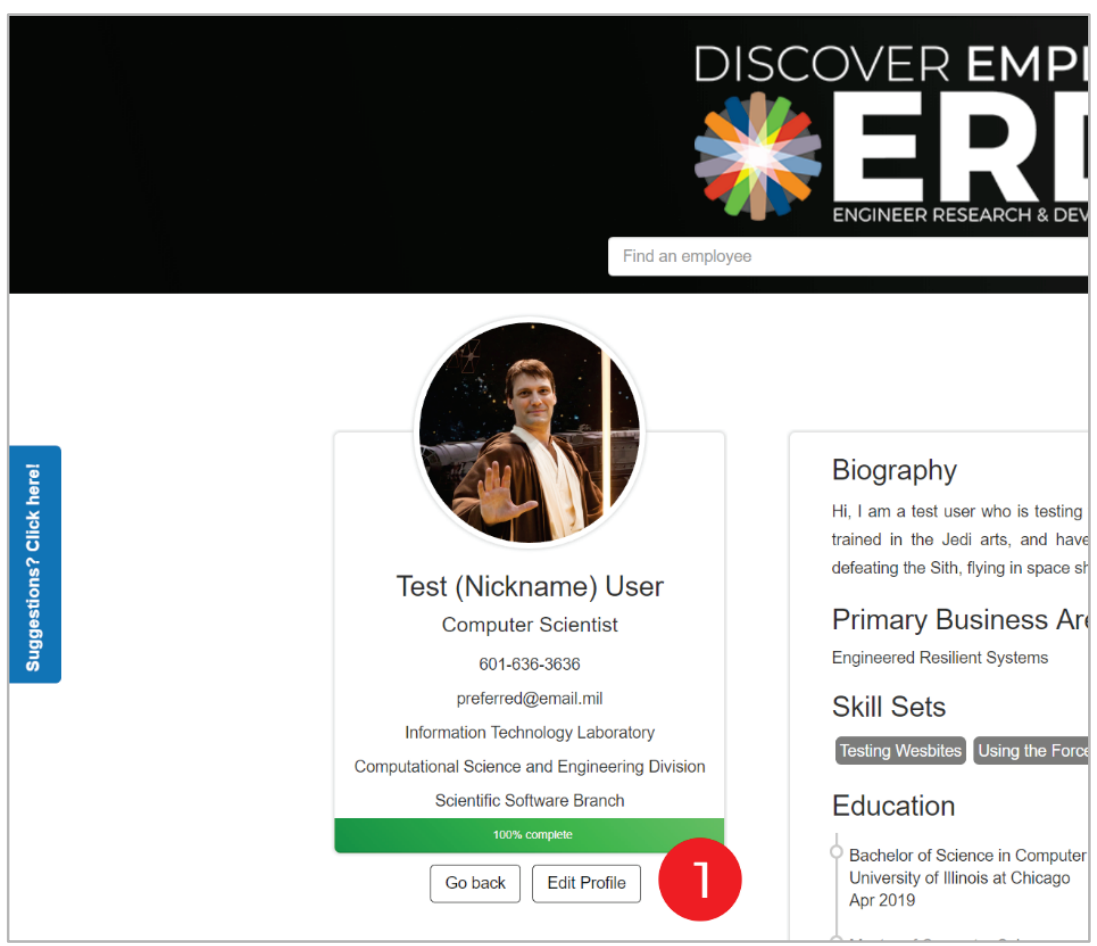

Clicking the People button in the top menu bar (as shown in Figure 1) will list all users in the system with the ability to filter by name or email. Click the Edit button to open the account editor for the selected user as shown in Figure 8. 
Figure 8. Edit a user's profile from the people view.

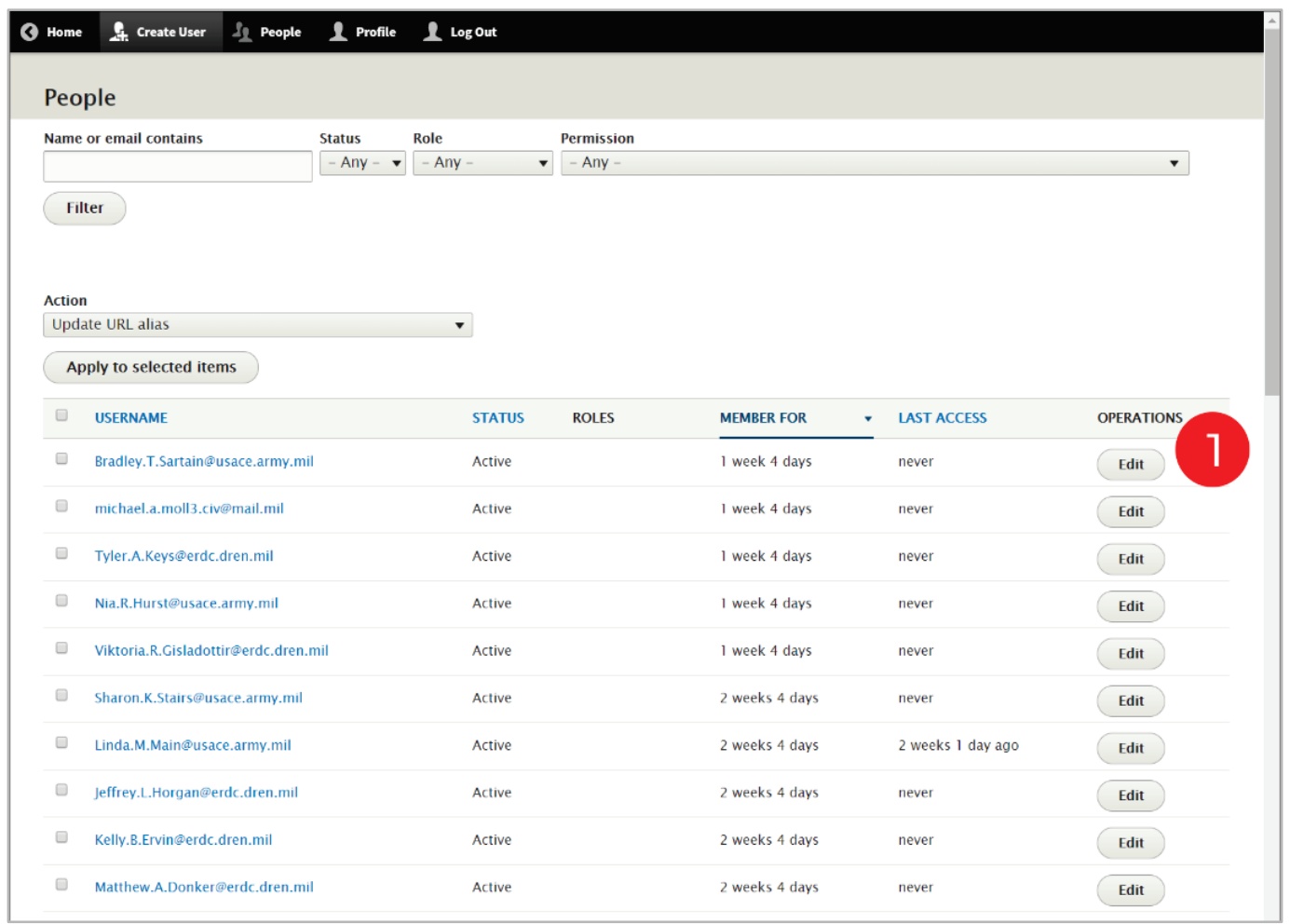




\section{Common Issues}

The most common issue with the system is authentication. Discover ERDC utilizes the RDE's SSO capability, which requires the use of a CAC and PIN. Have the user launch their preferred web browser (Microsoft Edge, Google Chrome, or Internet Explorer are recommended) and navigate to https://discover.erdc.dren.mil. Immediately, they will be asked to provide their credentials as seen in Figures 9 and 10. If not prompted, they will most likely receive a Ping error message with a red box, which should contain an error code along with the message. Have the user provide the message and code to put into a ticket for the SSO team.

Make sure the user chooses the "Authentication" certificate from their CAC. Selecting the wrong certificate may result in a failed authentication error message.

Figure 9. Certificate prompt in Google Chrome.

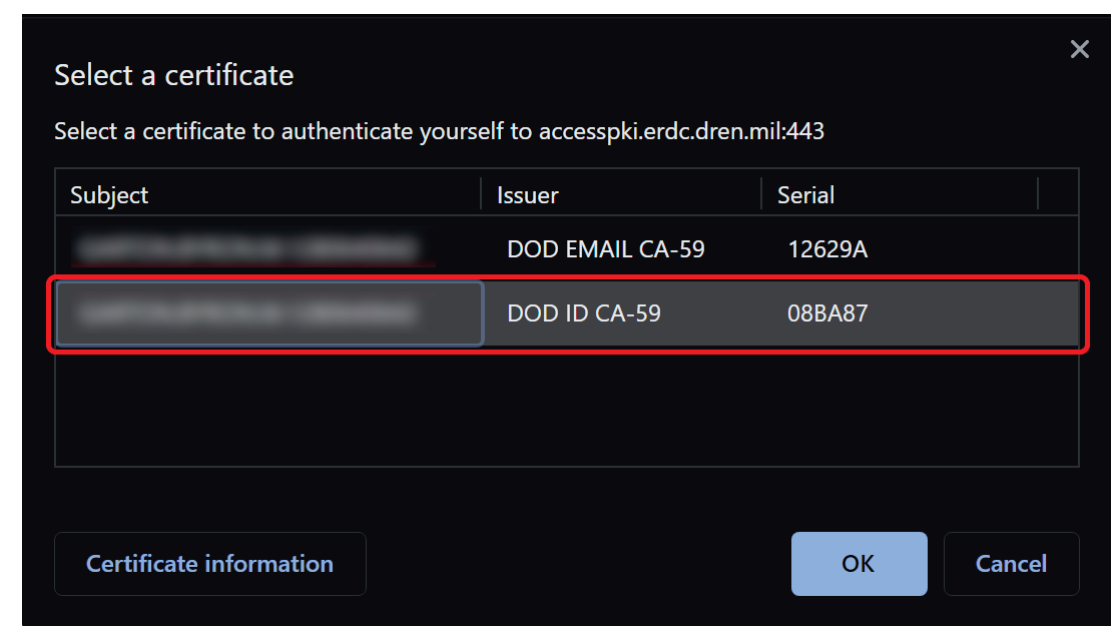


Figure 10. Certificate selection in Internet Explorer.

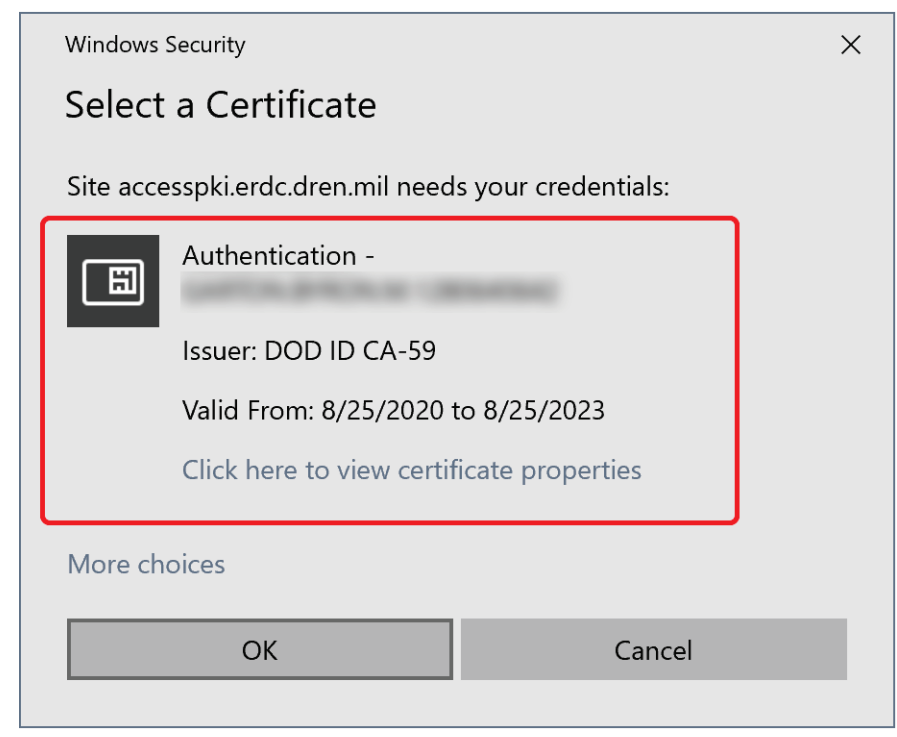

If the user receives an error message prior to seeing a certificate prompt or after selecting a certificate, they most likely need to clear the browser's cache. Please refer to the instructions for clearing browser cache in the Troubleshooting section of this document. If an error message is received after supplying their PIN, they have entered the PIN incorrectly or the browser failed to pass the credentials on to Discover ERDC. Try again with another browser after clearing the browser cache.

Occasionally, a user might get a notice that their account is temporarily blocked. This happens when their account in E-PAS has been marked as inactive, which typically happens when an employee retires, but it can also happen when they have not accessed the system in a long time. Advise the user to log into the E-PAS system periodically, then log into Discover ERDC to manage the user's account. Uncheck the box next to Blocked and click Save to re-enable the user's account. 


\section{Troubleshooting}

\section{Clearing browser cache}

Clearing the browser cache solves the majority of issues encountered on Discover ERDC. SSO authentication issues a token to the user's browser that passes their authentication session on to other systems that utilize SSO. This allows them to skip re-entering their CAC PIN over and over again when traversing between systems. The authentication tokens that are issued come with a lifespan of 8 hours; after the token is expired, the system will ask for their PIN again. If, for some reason, the token does not get reissued successfully, the user will see a red box similar to the ones shown in Figure 11.

Figure 11. Single sign on errors.
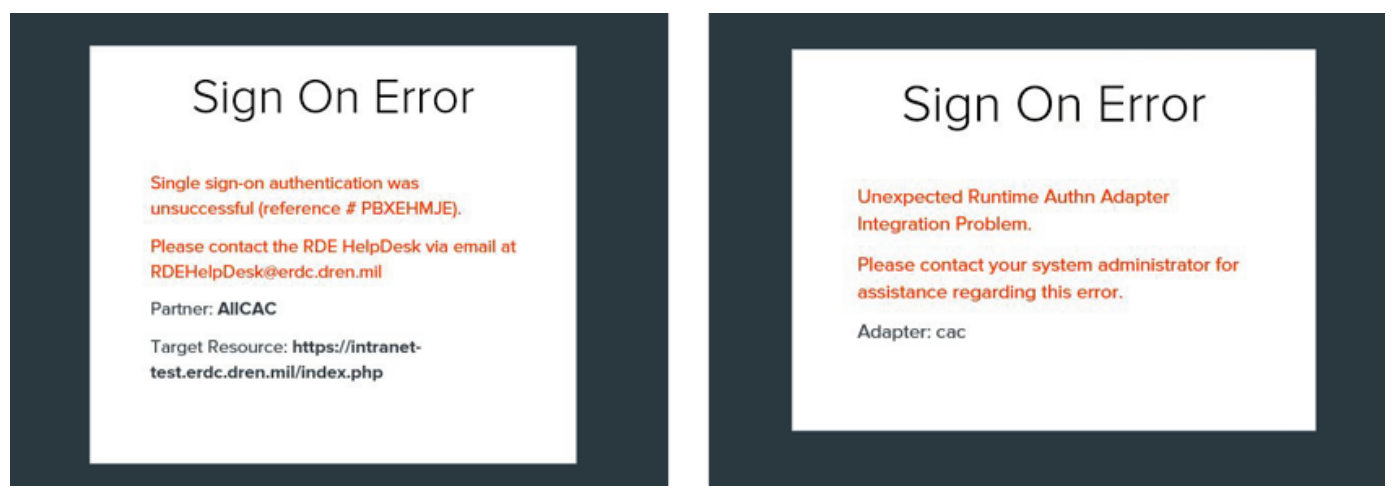

Most of the time these issues are fixable on the client side. The following documentation describes some methods for users to try and repair authentication problems on their computers.

\section{Internet Explorer 9,10,11}

1. Select Tools (via the Gear Icon) > Safety > Delete browsing history...

(NOTE: This menu can also be accessed by holding Ctrl + Shift + Delete.) 
Figure 12. Internet Explorer, step 1.

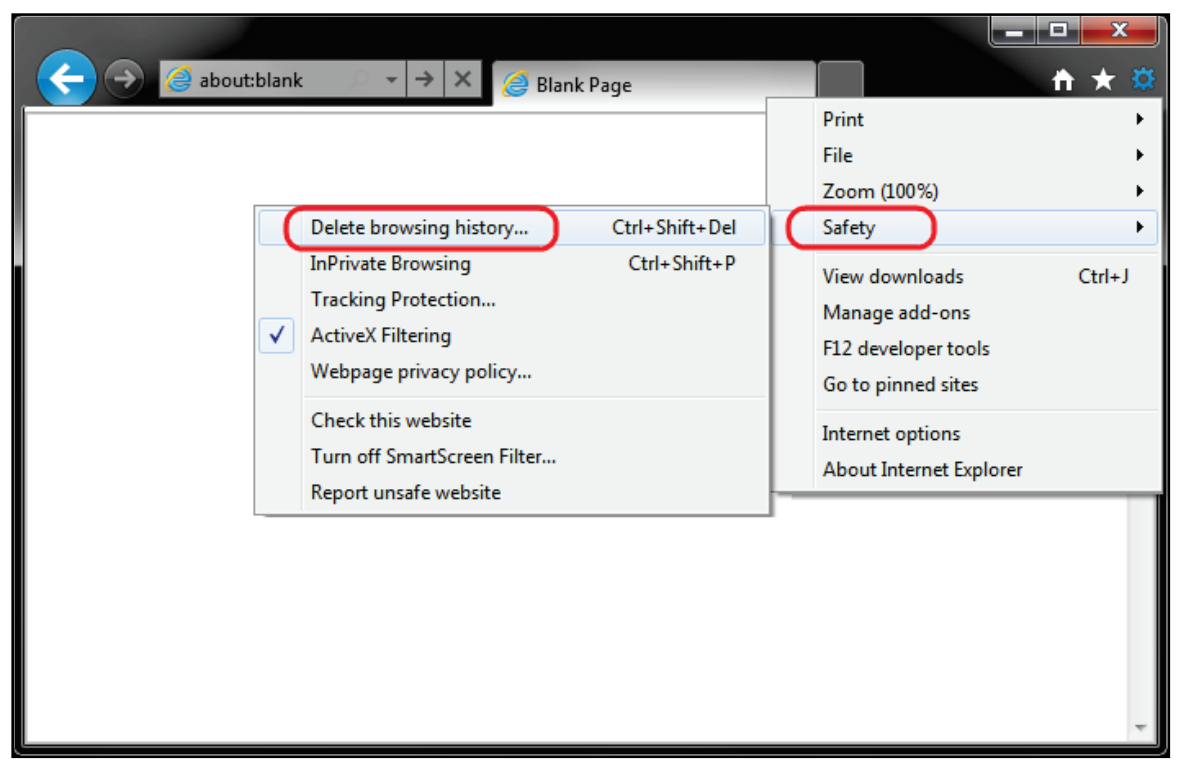

2. Make sure to uncheck Preserve Favorites website data and check both Temporary Internet Files and Cookies then click Delete.

Figure 13. Internet Explorer, step 2.

Delete Browsing History
Keep cookies and temporary Internet files that enable your favorite
websites to retain preferences and display faster.
Temporary Internet files
Copies of webpages, images, and media that are saved for faster
viewing.
Cookies
Files stored on your computer by websites to save preferences
such as login information.
History
List of websites you have visited.
Download History
List of files you have downloaded.
Form data
Saved information that you have typed into forms.
Passwords
Saved passwords that are automatically filled in when you sign in
to a website you've previously visited.
InPrivate Filtering data
Saved data used by InPrivate Filtering to detect where websites may
be automatically sharing details about your visit.


3. A confirmation at the bottom of the window will be shown once the cache and cookies have been successfully cleared.

Figure 14. Internet Explorer, step 3.

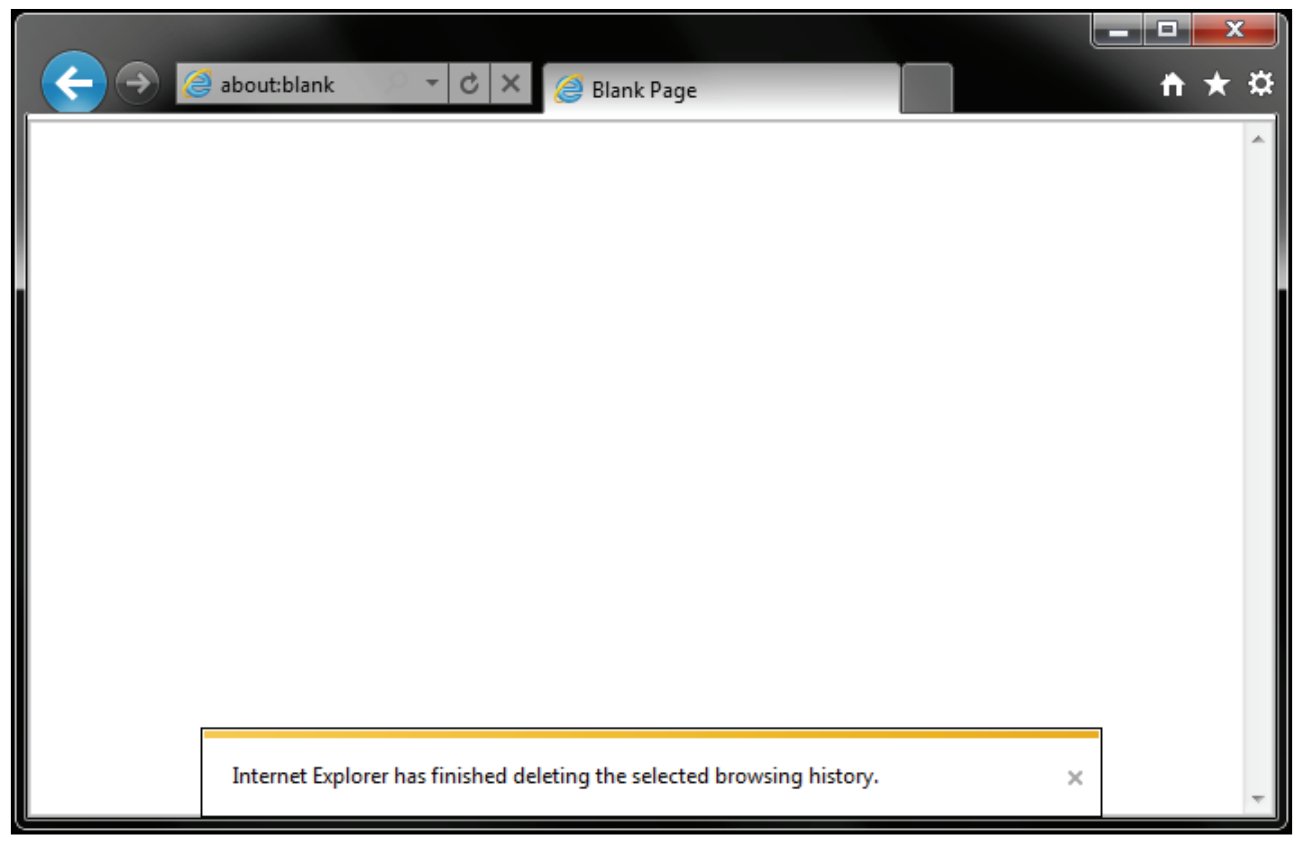

The above procedure for clearing cache and cookies should work for the majority of websites, but certain websites and applications may require a more thorough procedure. If still having issues, try the steps below.

(NOTE: The F12 developer tools in Internet Explorer 11 do not include a cache menu. This process will only work for Internet Explorer 10 or lower.)

1. Close out of Internet Options. Click on Tools and select Developer Tools. 
Figure 15. Internet Explorer developer tools, step 1.

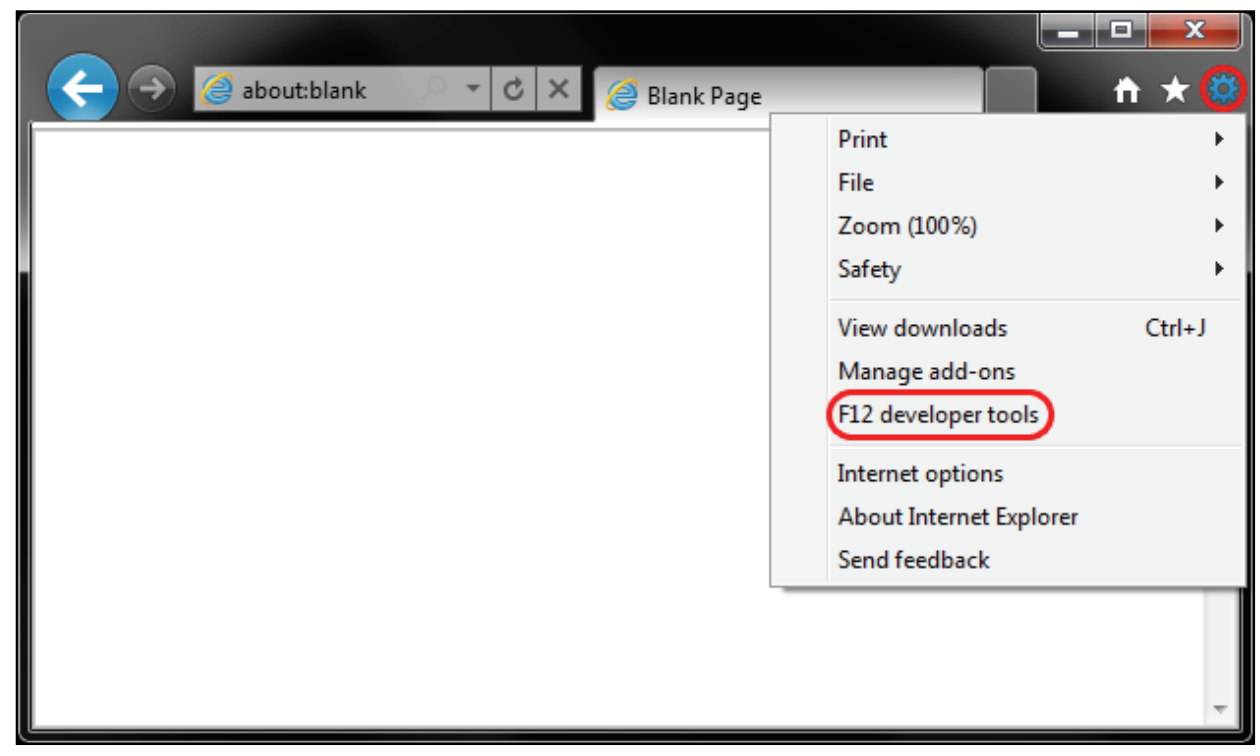

2. In the Developer Tools window, click on Cache and select Clear Browser Cache...

Figure 16. Internet Explorer developer tools, step 2.

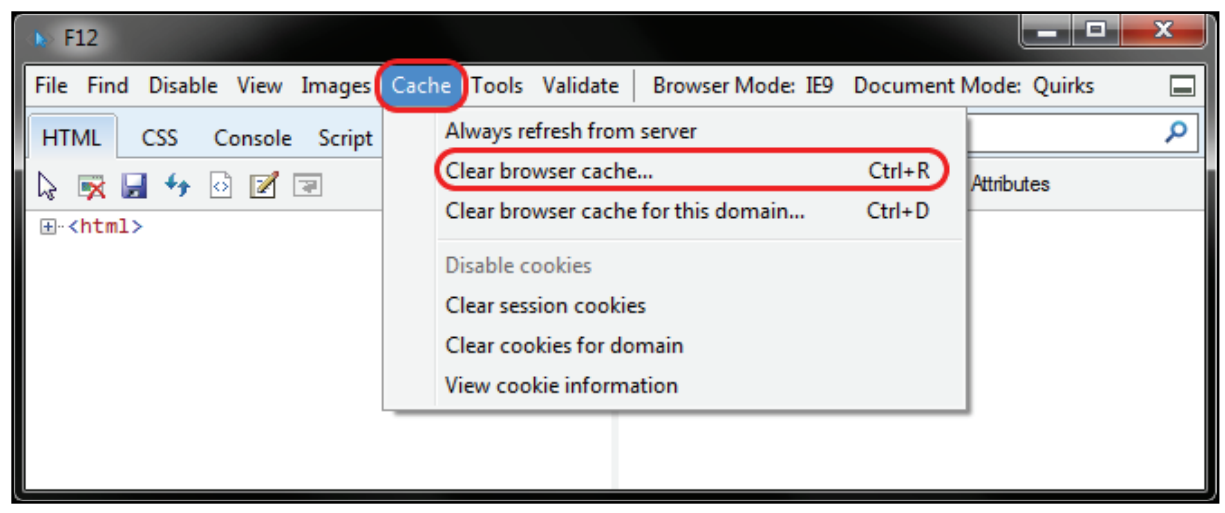

3. Click Yes to confirm the clearing of the browser cache.

Figure 17. Internet Explorer developer tools, step 3.

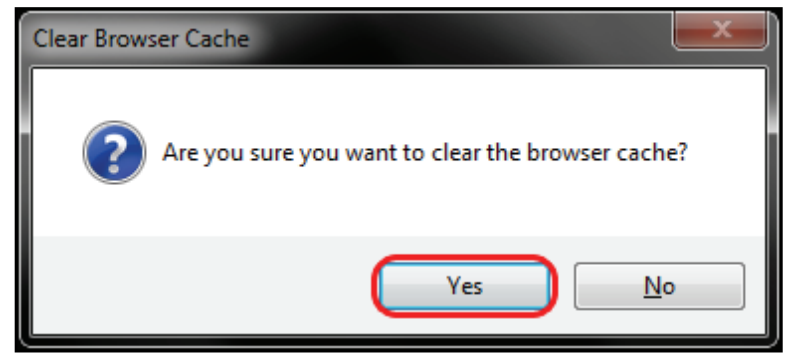


4. Restart Internet Explorer and return to the page you were attempting to access.

\section{Microsoft Edge}

1. Launch the Edge browser and click on the 3-lined Hub button in the top right corner.

2. Next, click on the clock-shaped History button.

3. Here, the browsing history will be able to be viewed.

Delete and clear the browsing history, cookies, data, temporary internet files, cache, etc. by clicking Clear History.

Figure 18. Microsoft Edge, step 1.

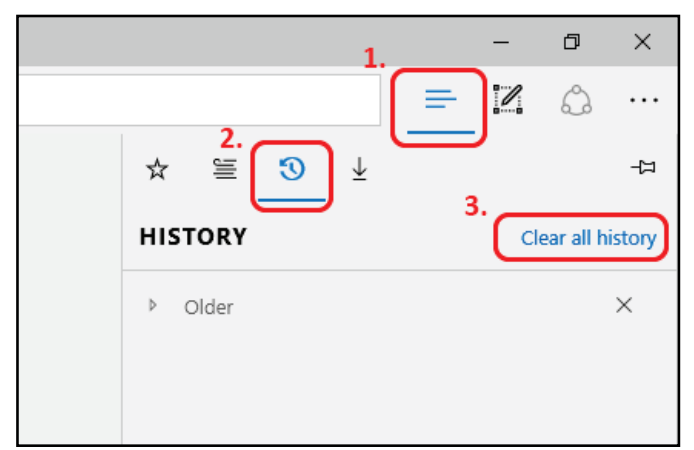

The following items are available:

- Browsing history

- Cookies and saved website data

- Cached data and files

- Download history

- Form data

- Passwords

Select Cookies and saved website data, Cached data and files, and Passwords, then click on the Clear button. 
Figure 19. Microsoft Edge, step 2.

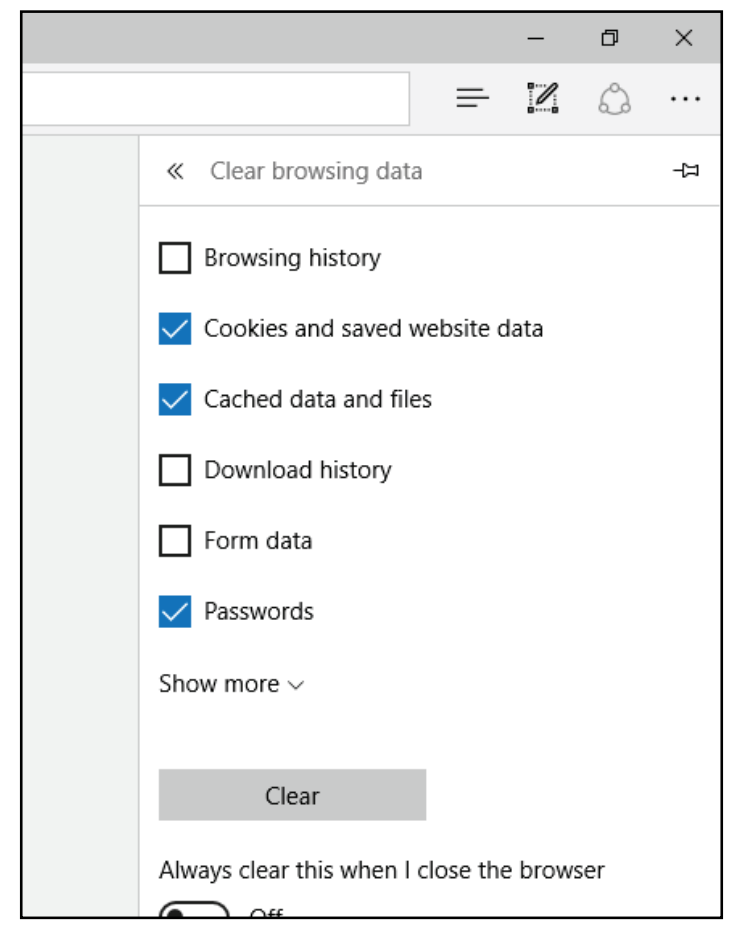

4. Restart Edge and return to the page you were attempting to access.

\section{Google Chrome}

Clearing the browser's cache and cookies means that website settings (like usernames and passwords) will be deleted and some sites might appear to be a little slower because all images will have to be reloaded.

1. Open Chrome.

2. On the browser toolbar, click More $\vdots>$ More Tools ${ }^{>}$Clear Browsing Data. 
Figure 20. Google Chrome, step 1.

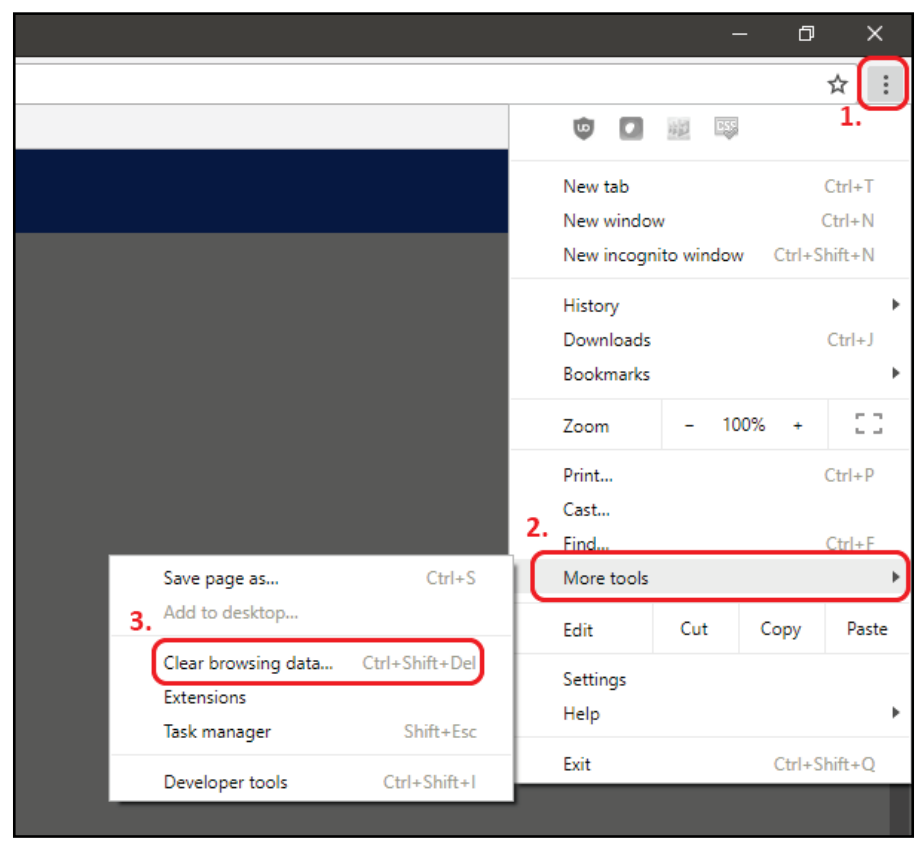

3. In the 'Clear browsing data' box, select the checkboxes for Cookies and other site data and Cached images and files.

4. Use the menu at the top to select the amount of data that you want to delete. Choose All time to delete everything.

5. Click Clear data.

Figure 21. Google Chrome, step 2.

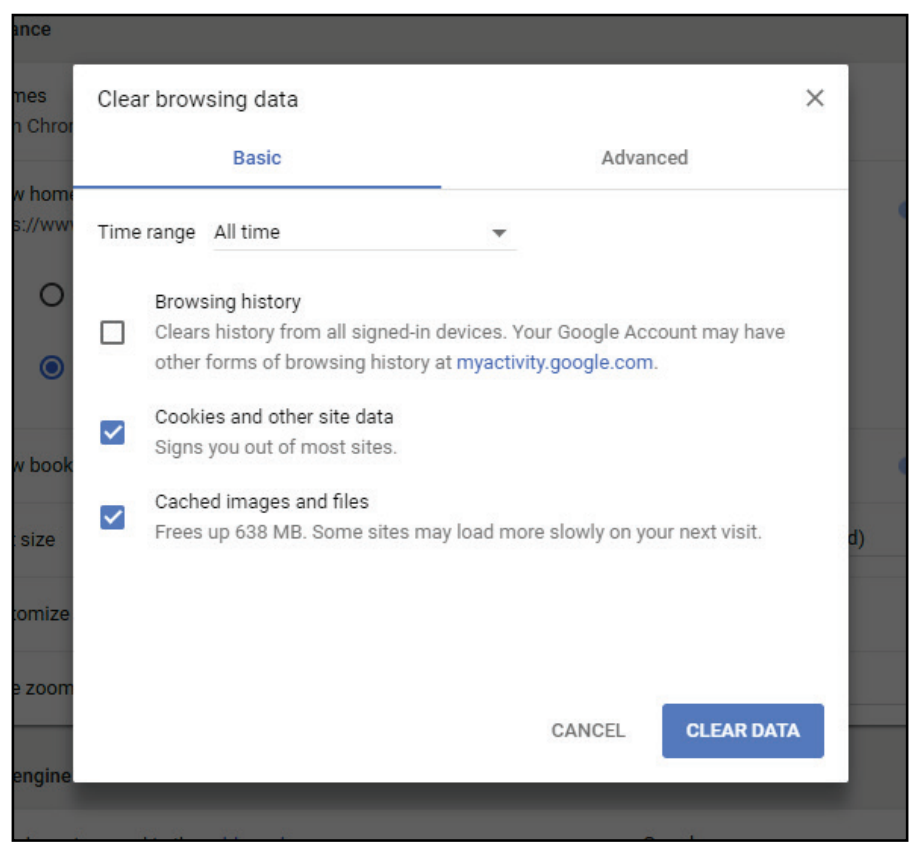




\section{Reset PIN cache}

Resetting PIN cache refers to the resetting of the CAC PIN information the user has previously entered when attempting to authenticate with the SSO system. Always attempt to clear browser cache before resetting PIN cache.

To reset PIN cache, close all browser windows, remove CAC from the reader, reinsert the CAC into the reader, then restart the browser.

On rare occasions, the user may have to repeat all steps and reboot their computer for the issue to be resolved. 


\section{Points of Contact}

Tisa Webb

Office of Research and Technology Transfer (ORTT)

601-634-4259

Antisa.C.Webb@usace.army.mil

Marty Garton

Information Technology Laboratory (ITL)

601-634-2888

Byron.M.Garton@erdc.dren.mil

Sage Broderick

Information Technology Laboratory (ITL)

601-634-2821

Sage.Broderick@erdc.dren.mil

Michael Clement

Information Technology Laboratory (ITL)

601-631-5138

Michael.A.Clement@erdc.dren.mil 


\section{Appendix A: Valid Office Codes}

The following office codes are valid in Discover ERDC at the time of this writing. Codes change as organizational changes are made, so these codes will require updating periodically. Some codes have several different valid options that are shown in parentheses. The options are separated by a $\mid$. If a user provides a code on their DD2875 form that is not listed in this table, verify with the user that the code is valid before proceeding. Entering an invalid code when creating a new account will result in failure to assign the proper organization names to their profile.

Table 1. Valid office codes.

\begin{tabular}{|c|c|c|c|}
\hline Office code & Office 1 & Office 2 & Office 3 \\
\hline CEERD-(ZA|Z) & Office of Director & & \\
\hline CEERD-ZAA & $\begin{array}{l}\text { Office of Associate } \\
\text { Director }\end{array}$ & & \\
\hline CEERD-ZAA-C & $\begin{array}{l}\text { Office of Associate } \\
\text { Director }\end{array}$ & $\begin{array}{l}\text { Corporate } \\
\text { Communication }\end{array}$ & \\
\hline CEERD-ZAA-L & $\begin{array}{l}\text { Office of Associate } \\
\text { Director }\end{array}$ & $\begin{array}{l}\text { Lab Personnel } \\
\text { Management Demo } \\
\text { Project Office }\end{array}$ & \\
\hline CEERD-JT & Office of Deputy Director & $\begin{array}{l}\text { JT\&E Program Support } \\
\text { Office }\end{array}$ & \\
\hline CEERD-(OC|OC-Z) & Office of Counsel & & \\
\hline CEERD-ZB & Office of Deputy Director & & \\
\hline CEERD-(ZBP|OP-Z) & Office of Deputy Director & Programs Office & \\
\hline CEERD-ZBT & Office of Deputy Director & $\begin{array}{l}\text { Office of Research and } \\
\text { Tech Transfer (ORTT) }\end{array}$ & \\
\hline CEERD-ZBT-E & Office of Deputy Director & $\begin{array}{l}\text { Office of Research and } \\
\text { Tech Transfer (ORTT) }\end{array}$ & ERDC Operations Center \\
\hline CEERD-ZBT-U & Office of Deputy Director & $\begin{array}{l}\text { Office of Research and } \\
\text { Tech Transfer (ORTT) }\end{array}$ & $\begin{array}{l}\text { USACE Reachback } \\
\text { Operations Center }\end{array}$ \\
\hline $\begin{array}{l}\text { CEERD-(ZBT-T|ZBT-O|ZBT- } \\
\text { A|ZBT-C) }\end{array}$ & Office of Deputy Director & $\begin{array}{l}\text { Office of Research and } \\
\text { Tech Transfer (ORTT) }\end{array}$ & $\begin{array}{l}\text { Technology, Knowledge \& } \\
\text { Outreach Div }\end{array}$ \\
\hline CEERD-ZBS & Office of Deputy Director & $\begin{array}{l}\text { Special Projects } \\
\text { Integration Office }\end{array}$ & \\
\hline CEERD-ZBH & Office of Deputy Director & $\begin{array}{l}\text { Directorate of Human } \\
\text { Capital }\end{array}$ & \\
\hline CEERD-ZBH-G & Office of Deputy Director & $\begin{array}{l}\text { Directorate of Human } \\
\text { Capital }\end{array}$ & Graduate Institute \\
\hline CEERD-(ZC|ZCM) & $\begin{array}{l}\text { Installation Operations } \\
\text { Command }\end{array}$ & & \\
\hline CEERD-LM-Z & $\begin{array}{l}\text { Installation Operations } \\
\text { Command }\end{array}$ & $\begin{array}{l}\text { Logistics Management } \\
\text { Office }\end{array}$ & \\
\hline CEERD-(CT|CT-SP|CT-ESS) & $\begin{array}{l}\text { Installation Operations } \\
\text { Command }\end{array}$ & Contracting Office & \\
\hline
\end{tabular}




\begin{tabular}{|c|c|c|c|}
\hline Office code & Office 1 & Office 2 & Office 3 \\
\hline CEERD-CTZ & $\begin{array}{l}\text { Installation Operations } \\
\text { Command }\end{array}$ & Contracting Office & Office of Chief \\
\hline CEERD-CTV & $\begin{array}{l}\text { Installation Operations } \\
\text { Command }\end{array}$ & Contracting Office & Vicksburg Branch \\
\hline CEERD-(CTS|CT-S) & $\begin{array}{l}\text { Installation Operations } \\
\text { Command }\end{array}$ & Contracting Office & Special Programs Branch \\
\hline CEERD-(CTC|CT-C) & $\begin{array}{l}\text { Installation Operations } \\
\text { Command }\end{array}$ & Contracting Office & $\begin{array}{l}\text { Champaign/Alexandria } \\
\text { Branch }\end{array}$ \\
\hline CEERD-(CTB|CT-B) & $\begin{array}{l}\text { Installation Operations } \\
\text { Command }\end{array}$ & Contracting Office & $\begin{array}{l}\text { Business Operations } \\
\text { Branch }\end{array}$ \\
\hline CEERD-IDZ & $\begin{array}{l}\text { Installation Operations } \\
\text { Command }\end{array}$ & Installation Support Div & \\
\hline $\begin{array}{l}\text { CEERD-(SO }|\mathrm{SOZ}| \mathrm{SO}-\mathrm{Z} \mid \mathrm{SO}- \\
\mathrm{ZA})\end{array}$ & $\begin{array}{l}\text { Installation Operations } \\
\text { Command }\end{array}$ & Installation Support Div & $\begin{array}{l}\text { Safety \& Environmental } \\
\text { Management Office }\end{array}$ \\
\hline $\begin{array}{l}\text { CEERD-(AO|AO- } \\
\text { MS|AOZ|AO-ZA) }\end{array}$ & $\begin{array}{l}\text { Installation Operations } \\
\text { Command }\end{array}$ & Installation Support Div & Internal Review Office \\
\hline $\begin{array}{l}\text { CEERD-(SEZ } \mid \text { SE- } \\
\text { Z } \mid \text { SE } \mid \text { SEC } \mid \text { SE-C } \mid \text { SE-I } \mid \text { SE- } \\
\text { IL } \mid \text { SE-MS } \mid \text { SE-P } \mid \text { SEV } \mid \text { SE-V) }\end{array}$ & $\begin{array}{l}\text { Installation Operations } \\
\text { Command }\end{array}$ & Installation Support Div & Security Office \\
\hline CEERD-(SES|SES-[VHC]) & $\begin{array}{l}\text { Installation Operations } \\
\text { Command }\end{array}$ & Installation Support Div & Security Programs \\
\hline CEERD-(SEG|SEG-[VHC]) & $\begin{array}{l}\text { Installation Operations } \\
\text { Command }\end{array}$ & Installation Support Div & Guard Services \\
\hline CEERD-SE-AS & $\begin{array}{l}\text { Installation Operations } \\
\text { Command }\end{array}$ & Installation Support Div & $\begin{array}{l}\text { Guard Services Branch } \\
\text { GRL }\end{array}$ \\
\hline CEERD-(SE-H|SEH) & $\begin{array}{l}\text { Installation Operations } \\
\text { Command }\end{array}$ & Installation Support Div & Security Office CRREL \\
\hline CEERD-SE-A & $\begin{array}{l}\text { Installation Operations } \\
\text { Command }\end{array}$ & Installation Support Div & Security Office GRL \\
\hline CEERD-(PW|PW-E) & $\begin{array}{l}\text { Installation Operations } \\
\text { Command }\end{array}$ & $\begin{array}{l}\text { Directorate of Public } \\
\text { Works }\end{array}$ & \\
\hline CEERD-PWZ-A & $\begin{array}{l}\text { Installation Operations } \\
\text { Command }\end{array}$ & $\begin{array}{l}\text { Directorate of Public } \\
\text { Works }\end{array}$ & Office of Director \\
\hline CEERD-PWZ-B & $\begin{array}{l}\text { Installation Operations } \\
\text { Command }\end{array}$ & $\begin{array}{l}\text { Directorate of Public } \\
\text { Works }\end{array}$ & Integration Cell \\
\hline CEERD-PWZ-I & $\begin{array}{l}\text { Installation Operations } \\
\text { Command }\end{array}$ & $\begin{array}{l}\text { Directorate of Public } \\
\text { Works }\end{array}$ & Facilities Group \\
\hline CEERD-(PWS|PW-S) & $\begin{array}{l}\text { Installation Operations } \\
\text { Command }\end{array}$ & $\begin{array}{l}\text { Directorate of Public } \\
\text { Works }\end{array}$ & R\&D Fabrication Group \\
\hline CEERD-(PW-C|PW-I) & $\begin{array}{l}\text { Installation Operations } \\
\text { Command }\end{array}$ & \begin{tabular}{|l} 
Directorate of Public \\
Works
\end{tabular} & Construction Division \\
\hline CEERD-PW-H & $\begin{array}{l}\text { Installation Operations } \\
\text { Command }\end{array}$ & $\begin{array}{l}\text { Directorate of Public } \\
\text { Works }\end{array}$ & $\begin{array}{l}\text { Operations Division } \\
\text { Hanover }\end{array}$ \\
\hline CEERD-PWF-EH & $\begin{array}{l}\text { Installation Operations } \\
\text { Command }\end{array}$ & $\begin{array}{l}\text { Directorate of Public } \\
\text { Works }\end{array}$ & Facility Engineer Hanover \\
\hline CEERD-PWF-EC & $\begin{array}{l}\text { Installation Operations } \\
\text { Command }\end{array}$ & $\begin{array}{l}\text { Directorate of Public } \\
\text { Works }\end{array}$ & $\begin{array}{l}\text { Facility Engineer } \\
\text { Champaign }\end{array}$ \\
\hline CEERD-(PWF-EV|PW-FE-V) & $\begin{array}{l}\text { Installation Operations } \\
\text { Command }\end{array}$ & $\begin{array}{l}\text { Directorate of Public } \\
\text { Works }\end{array}$ & $\begin{array}{l}\text { Facility Engineer } \\
\text { Vicksburg }\end{array}$ \\
\hline CEERD-SB & $\begin{array}{l}\text { Installation Operations } \\
\text { Command }\end{array}$ & $\begin{array}{l}\text { Office of Small Business } \\
\text { Programs }\end{array}$ & \\
\hline CEERD-BDZ & $\begin{array}{l}\text { Installation Operations } \\
\text { Command }\end{array}$ & $\begin{array}{l}\text { Business Support } \\
\text { Division }\end{array}$ & \\
\hline
\end{tabular}




\begin{tabular}{|c|c|c|c|}
\hline Office code & Office 1 & Office 2 & Office 3 \\
\hline CEERD-(EO|EOZ|EO-ZA) & $\begin{array}{l}\text { Installation Operations } \\
\text { Command }\end{array}$ & $\begin{array}{l}\text { Business Support } \\
\text { Division }\end{array}$ & $\begin{array}{l}\text { Equal Employment } \\
\text { Opportunity Office }\end{array}$ \\
\hline CEERD-(RM|RMZ) & $\begin{array}{l}\text { Installation Operations } \\
\text { Command }\end{array}$ & $\begin{array}{l}\text { Business Support } \\
\text { Division }\end{array}$ & $\begin{array}{l}\text { Directorate of Resource } \\
\text { Management }\end{array}$ \\
\hline CEERD-RMB & $\begin{array}{l}\text { Installation Operations } \\
\text { Command }\end{array}$ & $\begin{array}{l}\text { Business Support } \\
\text { Division }\end{array}$ & DRM-Budget Division \\
\hline $\begin{array}{l}\text { CEERD-(RMF|RMF-C|RM- } \\
\text { FC|RMF-Q|RM-FQ|RMF- } \\
\text { O|RM-FO) } \\
\end{array}$ & $\begin{array}{l}\text { Installation Operations } \\
\text { Command }\end{array}$ & $\begin{array}{l}\text { Business Support } \\
\text { Division }\end{array}$ & $\begin{array}{l}\text { DRM-Finance and } \\
\text { Accounting Branch }\end{array}$ \\
\hline CEERD-RMM & $\begin{array}{l}\text { Installation Operations } \\
\text { Command }\end{array}$ & $\begin{array}{l}\text { Business Support } \\
\text { Division }\end{array}$ & $\begin{array}{l}\text { DRM-Manpower and } \\
\text { Management Analysis } \\
\text { Branch }\end{array}$ \\
\hline CEERD-PVE & $\begin{array}{l}\text { Installation Operations } \\
\text { Command }\end{array}$ & $\begin{array}{l}\text { Business Support } \\
\text { Division }\end{array}$ & $\begin{array}{l}\text { Protocol, Visitors \& Events } \\
\text { Office }\end{array}$ \\
\hline CEERD-(PA|PA-A|PA-H) & $\begin{array}{l}\text { Installation Operations } \\
\text { Command }\end{array}$ & Public Affairs Office & \\
\hline CEERD-(PAZ|PA-Z|PA-ZA) & $\begin{array}{l}\text { Installation Operations } \\
\text { Command }\end{array}$ & Public Affairs Office & Office of Chief \\
\hline CEERD-ZCA & $\begin{array}{l}\text { Installation Operations } \\
\text { Command }\end{array}$ & $\begin{array}{l}\text { Deputy Command Staff } \\
\text { Div }\end{array}$ & \\
\hline CEERD-HVZ & $\begin{array}{l}\text { Coastal and Hydraulics } \\
\text { Laboratory }\end{array}$ & & \\
\hline CEERD-(HZA|HZ|HZY) & $\begin{array}{l}\text { Coastal and Hydraulics } \\
\text { Laboratory }\end{array}$ & Office of Director & \\
\hline CEERD-HZB & $\begin{array}{l}\text { Coastal and Hydraulics } \\
\text { Laboratory }\end{array}$ & Office of Deputy Director & \\
\hline $\begin{array}{l}\text { CEERD-(HZT }|\mathrm{HT}| \mathrm{HV}-\mathrm{B} \mid \mathrm{HV}- \\
\text { ZB) }\end{array}$ & $\begin{array}{l}\text { Coastal and Hydraulics } \\
\text { Laboratory }\end{array}$ & $\begin{array}{l}\text { Office of Technical } \\
\text { Directors }\end{array}$ & \\
\hline CEERD-(HZS|HS) & $\begin{array}{l}\text { Coastal and Hydraulics } \\
\text { Laboratory }\end{array}$ & Senior Scientists Group & \\
\hline CEERD-(HZM|HM) & $\begin{array}{l}\text { Coastal and Hydraulics } \\
\text { Laboratory }\end{array}$ & $\begin{array}{l}\text { Management Integration } \\
\text { Office }\end{array}$ & \\
\hline CEERD-HN & $\begin{array}{l}\text { Coastal and Hydraulics } \\
\text { Laboratory }\end{array}$ & Navigation Division & \\
\hline $\begin{array}{l}\text { CEERD-(HNF } \mid \text { HNF-M } \mid \text { HNF- } \\
\text { O) }\end{array}$ & $\begin{array}{l}\text { Coastal and Hydraulics } \\
\text { Laboratory }\end{array}$ & Navigation Division & $\begin{array}{l}\text { Field Data Collection \& } \\
\text { Analysis Branch }\end{array}$ \\
\hline $\begin{array}{l}\text { CEERD-(HNC|HN-C|HNC- } \\
\text { D|HN-CD } \mid \text { HNC-E } \mid \text { HN-CE) }\end{array}$ & $\begin{array}{l}\text { Coastal and Hydraulics } \\
\text { Laboratory }\end{array}$ & Navigation Division & $\begin{array}{l}\text { Coastal Engineering } \\
\text { Branch }\end{array}$ \\
\hline $\begin{array}{l}\text { CEERD-(HNN|HN-N|HNN- } \\
\text { D|HN-ND|HNN-F|HN- } \\
\text { NF|HNN-L|HN-NL) }\end{array}$ & $\begin{array}{l}\text { Coastal and Hydraulics } \\
\text { Laboratory }\end{array}$ & Navigation Division & Navigation Branch \\
\hline $\begin{array}{l}\text { CEERD-(HNH|HN-H|HNH- } \\
\text { E|HN-HE|HNH-H|HN- } \\
\text { HH|HNH-I|HN-HI|HNH- } \\
\text { S|HN-HS) }\end{array}$ & $\begin{array}{l}\text { Coastal and Hydraulics } \\
\text { Laboratory }\end{array}$ & Navigation Division & $\begin{array}{l}\text { Harbors, Entrances \& } \\
\text { Structures Branch }\end{array}$ \\
\hline CEERD-(HF|HF-FO) & $\begin{array}{l}\text { Coastal and Hydraulics } \\
\text { Laboratory }\end{array}$ & $\begin{array}{l}\text { Flood and Storm } \\
\text { Protection Division }\end{array}$ & \\
\hline $\begin{array}{l}\text { CEERD-(HFH|HF-H|HF- } \\
\text { HE|HFH-G|HF-HG|HFH- } \\
\text { W|HF-HW|HFH-R) }\end{array}$ & $\begin{array}{l}\text { Coastal and Hydraulics } \\
\text { Laboratory }\end{array}$ & $\begin{array}{l}\text { Flood and Storm } \\
\text { Protection Division }\end{array}$ & $\begin{array}{l}\text { Hydrologic Systems } \\
\text { Branch }\end{array}$ \\
\hline $\begin{array}{l}\text { CEERD-(HFC } \mid \text { HF-C } \mid \text { HF- } \\
\text { CS } \mid \text { HF-CT } \mid \text { HFC-I|HF- } \\
\text { CI } \mid \text { HFC-S } \mid \text { HFC-T) }\end{array}$ & $\begin{array}{l}\text { Coastal and Hydraulics } \\
\text { Laboratory }\end{array}$ & $\begin{array}{l}\text { Flood and Storm } \\
\text { Protection Division }\end{array}$ & Coastal Processes Branch \\
\hline
\end{tabular}




\begin{tabular}{|c|c|c|c|}
\hline Office code & Office 1 & Office 2 & Office 3 \\
\hline $\begin{array}{l}\text { CEERD-(HFE|HF-E|HF- } \\
\text { EL|HFE-L|HF-ES|HFE-S) }\end{array}$ & $\begin{array}{l}\text { Coastal and Hydraulics } \\
\text { Laboratory }\end{array}$ & $\begin{array}{l}\text { Flood and Storm } \\
\text { Protection Division }\end{array}$ & $\begin{array}{l}\text { Estuarine Engineering } \\
\text { Branch }\end{array}$ \\
\hline CEERD-(HFA|HF-A) & $\begin{array}{l}\text { Coastal and Hydraulics } \\
\text { Laboratory }\end{array}$ & $\begin{array}{l}\text { Flood and Storm } \\
\text { Protection Division }\end{array}$ & $\begin{array}{l}\text { Coastal Observation and } \\
\text { Analysis Branch }\end{array}$ \\
\hline $\begin{array}{l}\text { CEERD-(HFR|HF-R|HFR- } \\
\text { R|HF-FR|HFR-S|HF-RS) }\end{array}$ & $\begin{array}{l}\text { Coastal and Hydraulics } \\
\text { Laboratory }\end{array}$ & $\begin{array}{l}\text { Flood and Storm } \\
\text { Protection Division }\end{array}$ & River Engineering Branch \\
\hline CEERD-GVZ & \begin{tabular}{|l} 
Geotechnical and \\
Structures Laboratory
\end{tabular} & & \\
\hline CEERD-GZA & $\begin{array}{l}\text { Geotechnical and } \\
\text { Structures Laboratory }\end{array}$ & Office of Director & \\
\hline CEERD-GZB & $\begin{array}{l}\text { Geotechnical and } \\
\text { Structures Laboratory }\end{array}$ & Office of Deputy Director & \\
\hline CEERD-GZS & $\begin{array}{l}\text { Geotechnical and } \\
\text { Structures Laboratory }\end{array}$ & Senior Scientist Group & \\
\hline CEERD-GZT & \begin{tabular}{|l} 
Geotechnical and \\
Structures Laboratory
\end{tabular} & $\begin{array}{l}\text { Office of Technical } \\
\text { Directors }\end{array}$ & \\
\hline CEERD-GZM & \begin{tabular}{|l} 
Geotechnical and \\
Structures Laboratory
\end{tabular} & $\begin{array}{l}\text { Management Integration } \\
\text { Office }\end{array}$ & \\
\hline CEERD-GS & $\begin{array}{l}\text { Geotechnical and } \\
\text { Structures Laboratory }\end{array}$ & $\begin{array}{l}\text { Geosciences and } \\
\text { Structures Division }\end{array}$ & \\
\hline CEERD-GSR & \begin{tabular}{|l} 
Geotechnical and \\
Structures Laboratory
\end{tabular} & \begin{tabular}{|l} 
Geosciences and \\
Structures Division \\
\end{tabular} & GSD Research Group \\
\hline CEERD-(GSG|GS-G) & $\begin{array}{l}\text { Geotechnical and } \\
\text { Structures Laboratory }\end{array}$ & $\begin{array}{l}\text { Geosciences and } \\
\text { Structures Division }\end{array}$ & $\begin{array}{l}\text { Geotechnical Engineering } \\
\text { and Geosciences Branch }\end{array}$ \\
\hline CEERD-(GSM|GS-M) & $\begin{array}{l}\text { Geotechnical and } \\
\text { Structures Laboratory }\end{array}$ & $\begin{array}{l}\text { Geosciences and } \\
\text { Structures Division }\end{array}$ & $\begin{array}{l}\text { Structural Mechanics } \\
\text { Branch }\end{array}$ \\
\hline CEERD-(GSS|GS-S) & \begin{tabular}{|l} 
Geotechnical and \\
Structures Laboratory
\end{tabular} & $\begin{array}{l}\text { Geosciences and } \\
\text { Structures Division }\end{array}$ & $\begin{array}{l}\text { Structural Engineering } \\
\text { Branch }\end{array}$ \\
\hline CEERD-(GSV|GS-V) & \begin{tabular}{|l} 
Geotechnical and \\
Structures Laboratory
\end{tabular} & $\begin{array}{l}\text { Geosciences and } \\
\text { Structures Division }\end{array}$ & $\begin{array}{l}\text { Survivability Engineering } \\
\text { Branch }\end{array}$ \\
\hline CEERD-(GM|GM-T) & $\begin{array}{l}\text { Geotechnical and } \\
\text { Structures Laboratory }\end{array}$ & $\begin{array}{l}\text { Engineering Systems and } \\
\text { Materials Division }\end{array}$ & \\
\hline CEERD-(GMR/GM-R) & \begin{tabular}{|l} 
Geotechnical and \\
Structures Laboratory
\end{tabular} & $\begin{array}{l}\text { Engineering Systems and } \\
\text { Materials Division }\end{array}$ & ESMD Research Group \\
\hline CEERD-(GMC|GM-C) & \begin{tabular}{|l} 
Geotechnical and \\
Structures Laboratory
\end{tabular} & $\begin{array}{l}\text { Engineering Systems and } \\
\text { Materials Division }\end{array}$ & $\begin{array}{l}\text { Concrete and Materials } \\
\text { Branch }\end{array}$ \\
\hline CEERD-(GMI|GM-I) & \begin{tabular}{|l} 
Geotechnical and \\
Structures Laboratory
\end{tabular} & $\begin{array}{l}\text { Engineering Systems and } \\
\text { Materials Division }\end{array}$ & $\begin{array}{l}\text { Impact and Explosion } \\
\text { Effects Branch }\end{array}$ \\
\hline CEERD-(GMA|GM-A) & \begin{tabular}{|l} 
Geotechnical and \\
Structures Laboratory
\end{tabular} & $\begin{array}{l}\text { Engineering Systems and } \\
\text { Materials Division }\end{array}$ & $\begin{array}{l}\text { Airfields and Pavements } \\
\text { Branch }\end{array}$ \\
\hline CEERD-(GMM|GM-M) & $\begin{array}{l}\text { Geotechnical and } \\
\text { Structures Laboratory }\end{array}$ & $\begin{array}{l}\text { Engineering Systems and } \\
\text { Materials Division }\end{array}$ & Mobility Systems Branch \\
\hline $\begin{array}{l}\text { CEERD-(EM|EM-D|EM- } \\
J \mid \text { EM-W) }\end{array}$ & $\begin{array}{l}\text { Environmental } \\
\text { Laboratory }\end{array}$ & & \\
\hline CEERD-EZA & $\begin{array}{l}\text { Environmental } \\
\text { Laboratory }\end{array}$ & Office of Director & \\
\hline CEERD-EZB & $\begin{array}{l}\text { Environmental } \\
\text { Laboratory }\end{array}$ & Office of Deputy Director & \\
\hline CEERD-EZS & $\begin{array}{l}\text { Environmental } \\
\text { Laboratory }\end{array}$ & $\begin{array}{l}\text { Senior Research } \\
\text { Scientists }\end{array}$ & \\
\hline CEERD-EZT & $\begin{array}{l}\text { Environmental } \\
\text { Laboratory }\end{array}$ & $\begin{array}{l}\text { Office of Technical } \\
\text { Directors }\end{array}$ & \\
\hline
\end{tabular}




\begin{tabular}{|c|c|c|c|}
\hline Office code & Office 1 & Office 2 & Office 3 \\
\hline CEERD-EZT-ES & $\begin{array}{l}\text { Environmental } \\
\text { Laboratory }\end{array}$ & $\begin{array}{l}\text { Office of Technical } \\
\text { Directors }\end{array}$ & $\begin{array}{l}\text { Environmental } \\
\text { Engineering \& Science }\end{array}$ \\
\hline CEERD-EZT-SS & $\begin{array}{l}\text { Environmental } \\
\text { Laboratory }\end{array}$ & $\begin{array}{l}\text { Office of Technical } \\
\text { Directors }\end{array}$ & $\begin{array}{l}\text { Environmental Science \& } \\
\text { Simulation }\end{array}$ \\
\hline CEERD-EZT-M & $\begin{array}{l}\text { Environmental } \\
\text { Laboratory }\end{array}$ & $\begin{array}{l}\text { Office of Technical } \\
\text { Directors }\end{array}$ & Military \\
\hline CEERD-EZM & $\begin{array}{l}\text { Environmental } \\
\text { Laboratory }\end{array}$ & $\begin{array}{l}\text { Management Integration } \\
\text { Office }\end{array}$ & \\
\hline CEERD-EP & $\begin{array}{l}\text { Environmental } \\
\text { Laboratory }\end{array}$ & $\begin{array}{l}\text { Environmental Processes } \\
\text { and Engineering Division }\end{array}$ & \\
\hline CEERD-(EPE|EP-E) & $\begin{array}{l}\text { Environmental } \\
\text { Laboratory }\end{array}$ & $\begin{array}{l}\text { Environmental Processes } \\
\text { and Engineering Division }\end{array}$ & $\begin{array}{l}\text { Environmental } \\
\text { Engineering Branch }\end{array}$ \\
\hline CEERD-EPC & $\begin{array}{l}\text { Environmental } \\
\text { Laboratory }\end{array}$ & $\begin{array}{l}\text { Environmental Processes } \\
\text { and Engineering Division }\end{array}$ & $\begin{array}{l}\text { Environmental Chemistry } \\
\text { Branch }\end{array}$ \\
\hline CEERD-(EPR|EP-R) & $\begin{array}{l}\text { Environmental } \\
\text { Laboratory }\end{array}$ & $\begin{array}{l}\text { Environmental Processes } \\
\text { and Engineering Division }\end{array}$ & $\begin{array}{l}\text { Environmental Risk } \\
\text { Assessment Branch }\end{array}$ \\
\hline CEERD-EPP & $\begin{array}{l}\text { Environmental } \\
\text { Laboratory }\end{array}$ & $\begin{array}{l}\text { Environmental Processes } \\
\text { and Engineering Division }\end{array}$ & $\begin{array}{l}\text { Environmental Processes } \\
\text { Branch }\end{array}$ \\
\hline CEERD-(EPW|EP-W) & $\begin{array}{l}\text { Environmental } \\
\text { Laboratory }\end{array}$ & $\begin{array}{l}\text { Environmental Processes } \\
\text { and Engineering Division }\end{array}$ & $\begin{array}{l}\text { Water Quality \& } \\
\text { Containment Modeling } \\
\text { Branch }\end{array}$ \\
\hline CEERD-EE & $\begin{array}{l}\text { Environmental } \\
\text { Laboratory }\end{array}$ & $\begin{array}{l}\text { Ecosystem Evaluation } \\
\text { and Engineering Division }\end{array}$ & \\
\hline CEERD-EEA & $\begin{array}{l}\text { Environmental } \\
\text { Laboratory }\end{array}$ & \begin{tabular}{|l|}
$\begin{array}{l}\text { Ecosystem Evaluation } \\
\text { and Engineering Division }\end{array}$ \\
\end{tabular} & \begin{tabular}{|l|} 
Aquatic Ecology and \\
Invasive Species Branch \\
\end{tabular} \\
\hline CEERD-EEW & $\begin{array}{l}\text { Environmental } \\
\text { Laboratory }\end{array}$ & $\begin{array}{l}\text { Ecosystem Evaluation } \\
\text { and Engineering Division }\end{array}$ & $\begin{array}{l}\text { Wetlands and Coastal } \\
\text { Ecology Branch }\end{array}$ \\
\hline CEERD-EEC & $\begin{array}{l}\text { Environmental } \\
\text { Laboratory }\end{array}$ & $\begin{array}{l}\text { Ecosystem Evaluation } \\
\text { and Engineering Division }\end{array}$ & $\begin{array}{l}\text { Environmental Systems } \\
\text { Branch }\end{array}$ \\
\hline CEERD-EEE & $\begin{array}{l}\text { Environmental } \\
\text { Laboratory }\end{array}$ & \begin{tabular}{|l|}
$\begin{array}{l}\text { Ecosystem Evaluation } \\
\text { and Engineering Division }\end{array}$ \\
\end{tabular} & $\begin{array}{l}\text { Ecological Resources } \\
\text { Branch }\end{array}$ \\
\hline CEERD-CVZ & $\begin{array}{l}\text { Construction Engineering } \\
\text { Research Laboratory }\end{array}$ & & \\
\hline CEERD-CZA & \begin{tabular}{|l|} 
Construction Engineering \\
Research Laboratory
\end{tabular} & Office of Director & \\
\hline CEERD-CZB & $\begin{array}{l}\text { Construction Engineering } \\
\text { Research Laboratory }\end{array}$ & Office of Deputy Director & \\
\hline CEERD-CZT & $\begin{array}{l}\text { Construction Engineering } \\
\text { Research Laboratory }\end{array}$ & $\begin{array}{l}\text { Office of Technical } \\
\text { Directors }\end{array}$ & \\
\hline CEERD-CZM & $\begin{array}{l}\text { Construction Engineering } \\
\text { Research Laboratory }\end{array}$ & $\begin{array}{l}\text { Management Integration } \\
\text { Office }\end{array}$ & \\
\hline CEERD-CF & $\begin{array}{l}\text { Construction Engineering } \\
\text { Research Laboratory }\end{array}$ & Facilities Division & \\
\hline CEERD-(CFE|CF-E) & $\begin{array}{l}\text { Construction Engineering } \\
\text { Research Laboratory }\end{array}$ & Facilities Division & Energy Branch \\
\hline CEERD-(CFM|CF-M) & $\begin{array}{l}\text { Construction Engineering } \\
\text { Research Laboratory }\end{array}$ & Facilities Division & $\begin{array}{l}\text { Materials \& Structures } \\
\text { Branch }\end{array}$ \\
\hline CEERD-(CFN|CF-N) & \begin{tabular}{|l|} 
Construction Engineering \\
Research Laboratory
\end{tabular} & Facilities Division & $\begin{array}{l}\text { Engineering Processes } \\
\text { Branch }\end{array}$ \\
\hline CEERD-CN & \begin{tabular}{|l|} 
Construction Engineering \\
Research Laboratory
\end{tabular} & Installations Division & \\
\hline CEERD-(CNC|CN-C) & $\begin{array}{l}\text { Construction Engineering } \\
\text { Research Laboratory }\end{array}$ & Installations Division & $\begin{array}{l}\text { Land \& Heritage } \\
\text { Conservation Branch }\end{array}$ \\
\hline
\end{tabular}




\begin{tabular}{|c|c|c|c|}
\hline Office code & Office 1 & Office 2 & Office 3 \\
\hline CEERD-(CNE $\mid \mathrm{CN}-\mathrm{E})$ & $\begin{array}{l}\text { Construction Engineering } \\
\text { Research Laboratory }\end{array}$ & Installations Division & $\begin{array}{l}\text { Environmental Processes } \\
\text { Branch }\end{array}$ \\
\hline CEERD-(CNN|CN-N) & $\begin{array}{l}\text { Construction Engineering } \\
\text { Research Laboratory }\end{array}$ & Installations Division & $\begin{array}{l}\text { Ecological Processes } \\
\text { Branch }\end{array}$ \\
\hline CEERD-(RVZ|RX) & $\begin{array}{l}\text { Cold Regions Research } \\
\text { and Engineering } \\
\text { Laboratory }\end{array}$ & & \\
\hline CEERD-(RZA|RV-ZA) & $\begin{array}{l}\text { Cold Regions Research } \\
\text { and Engineering } \\
\text { Laboratory }\end{array}$ & Office of Director & \\
\hline CEERD-(RZB|RV-ZB) & $\begin{array}{l}\text { Cold Regions Research } \\
\text { and Engineering } \\
\text { Laboratory }\end{array}$ & Office of Deputy Director & \\
\hline CEERD-(RZT |RV-T) & $\begin{array}{l}\text { Cold Regions Research } \\
\text { and Engineering } \\
\text { Laboratory }\end{array}$ & $\begin{array}{l}\text { Office of Technical } \\
\text { Directors }\end{array}$ & \\
\hline CEERD-(RZM|RV-M) & $\begin{array}{l}\text { Cold Regions Research } \\
\text { and Engineering } \\
\text { Laboratory }\end{array}$ & $\begin{array}{l}\text { Management Integration } \\
\text { Office }\end{array}$ & \\
\hline CEERD-RR & $\begin{array}{l}\text { Cold Regions Research } \\
\text { and Engineering } \\
\text { Laboratory }\end{array}$ & $\begin{array}{l}\text { Research \& Engineering } \\
\text { Division }\end{array}$ & \\
\hline CEERD-(RRN|RR-N) & $\begin{array}{l}\text { Cold Regions Research } \\
\text { and Engineering } \\
\text { Laboratory }\end{array}$ & $\begin{array}{l}\text { Research \& Engineering } \\
\text { Division }\end{array}$ & $\begin{array}{l}\text { Biogeochemical Sciences } \\
\text { Branch }\end{array}$ \\
\hline CEERD-(RRD|RR-D) & $\begin{array}{l}\text { Cold Regions Research } \\
\text { and Engineering } \\
\text { Laboratory }\end{array}$ & $\begin{array}{l}\text { Research \& Engineering } \\
\text { Division }\end{array}$ & Signature Physics Branch \\
\hline CEERD-(RRG|RR-G) & $\begin{array}{l}\text { Cold Regions Research } \\
\text { and Engineering } \\
\text { Laboratory }\end{array}$ & $\begin{array}{l}\text { Research \& Engineering } \\
\text { Division }\end{array}$ & $\begin{array}{l}\text { Terrestrial \& Cryospheric } \\
\text { Sciences Branch }\end{array}$ \\
\hline CEERD-(RRH|RR-H) & $\begin{array}{l}\text { Cold Regions Research } \\
\text { and Engineering } \\
\text { Laboratory }\end{array}$ & $\begin{array}{l}\text { Research \& Engineering } \\
\text { Division }\end{array}$ & $\begin{array}{l}\text { Force Protection and } \\
\text { Sustainment Branch }\end{array}$ \\
\hline $\begin{array}{l}\text { CEERD-(RZE }|\mathrm{RV}-\mathrm{E}| \mathrm{RRE} \mid \mathrm{RR}- \\
\mathrm{E})\end{array}$ & $\begin{array}{l}\text { Cold Regions Research } \\
\text { and Engineering } \\
\text { Laboratory }\end{array}$ & $\begin{array}{l}\text { Research \& Engineering } \\
\text { Division }\end{array}$ & $\begin{array}{l}\text { Engineering Resources } \\
\text { Branch }\end{array}$ \\
\hline CEERD-(RRS|RS) & $\begin{array}{l}\text { Cold Regions Research } \\
\text { and Engineering } \\
\text { Laboratory }\end{array}$ & $\begin{array}{l}\text { RS/GIS Center of } \\
\text { Expertise }\end{array}$ & \\
\hline CEERD-RR-C & $\begin{array}{l}\text { Cold Regions Research } \\
\text { and Engineering } \\
\text { Laboratory }\end{array}$ & $\begin{array}{l}\text { RS/GIS Center of } \\
\text { Expertise }\end{array}$ & \\
\hline CEERD-IZ & $\begin{array}{l}\text { Information Technology } \\
\text { Laboratory }\end{array}$ & & \\
\hline CEERD-IZA & $\begin{array}{l}\text { Information Technology } \\
\text { Laboratory }\end{array}$ & Office of Director & \\
\hline CEERD-(IZB|IV-ZB) & $\begin{array}{l}\text { Information Technology } \\
\text { Laboratory }\end{array}$ & Office of Deputy Director & \\
\hline CEERD-IZT & $\begin{array}{l}\text { Information Technology } \\
\text { Laboratory }\end{array}$ & $\begin{array}{l}\text { Office of Technical } \\
\text { Directors }\end{array}$ & \\
\hline CEERD-IZM & $\begin{array}{l}\text { Information Technology } \\
\text { Laboratory }\end{array}$ & $\begin{array}{l}\text { Management Integration } \\
\text { Office }\end{array}$ & \\
\hline
\end{tabular}




\begin{tabular}{|c|c|c|c|}
\hline Office code & Office 1 & Office 2 & Office 3 \\
\hline CEERD-IZP & $\begin{array}{l}\text { Information Technology } \\
\text { Laboratory }\end{array}$ & \begin{tabular}{|l|} 
DOD High Performance \\
Computing \\
Modernization Program \\
\end{tabular} & \\
\hline CEERD-IZO & $\begin{array}{l}\text { Information Technology } \\
\text { Laboratory }\end{array}$ & $\begin{array}{l}\text { Office of the Chief } \\
\text { Information Officer }\end{array}$ & \\
\hline CEERD-II & $\begin{array}{l}\text { Information Technology } \\
\text { Laboratory }\end{array}$ & \begin{tabular}{|l} 
Infrastructure \& \\
Knowledge Management
\end{tabular} & \\
\hline CEERD-II-I & $\begin{array}{l}\text { Information Technology } \\
\text { Laboratory }\end{array}$ & $\begin{array}{l}\text { Infrastructure \& } \\
\text { Knowledge Management }\end{array}$ & $\begin{array}{l}\text { Information Assurance } \\
\text { Team }\end{array}$ \\
\hline CEERD-II-S & \begin{tabular}{|l|}
$\begin{array}{l}\text { Information Technology } \\
\text { Laboratory }\end{array}$ \\
\end{tabular} & $\begin{array}{l}\text { Infrastructure \& } \\
\text { Knowledge Management }\end{array}$ & Computer Systems Branch \\
\hline CEERD-II-C & $\begin{array}{l}\text { Information Technology } \\
\text { Laboratory }\end{array}$ & $\begin{array}{l}\text { Infrastructure \& } \\
\text { Knowledge Management }\end{array}$ & $\begin{array}{l}\text { Communication } \\
\text { Infrastructure \& } \\
\text { Architecture Branch }\end{array}$ \\
\hline CEERD-II-K & $\begin{array}{l}\text { Information Technology } \\
\text { Laboratory }\end{array}$ & $\begin{array}{l}\text { Infrastructure \& } \\
\text { Knowledge Management }\end{array}$ & $\begin{array}{l}\text { Information \& Knowledge } \\
\text { Sciences Branch }\end{array}$ \\
\hline CEERD-II-P & \begin{tabular}{|l} 
Information Technology \\
Laboratory \\
\end{tabular} & \begin{tabular}{|l|} 
Infrastructure \& \\
Knowledge Management
\end{tabular} & $\begin{array}{l}\text { Publishing \& Technology } \\
\text { Transfer Branch }\end{array}$ \\
\hline CEERD-II-M & $\begin{array}{l}\text { Information Technology } \\
\text { Laboratory }\end{array}$ & \begin{tabular}{|l} 
Infrastructure \& \\
Knowledge Management
\end{tabular} & $\begin{array}{l}\text { Multimedia Presentation } \\
\text { Branch }\end{array}$ \\
\hline CEERD-(IE|IED|IE-D) & $\begin{array}{l}\text { Information Technology } \\
\text { Laboratory }\end{array}$ & $\begin{array}{l}\text { Computational Science } \\
\text { and Engineering Division }\end{array}$ & \\
\hline CEERD-(IEC|IE-C) & $\begin{array}{l}\text { Information Technology } \\
\text { Laboratory } \\
\end{array}$ & $\begin{array}{l}\text { Computational Science } \\
\text { and Engineering Division }\end{array}$ & $\begin{array}{l}\text { Computational Analysis } \\
\text { Branch }\end{array}$ \\
\hline CEERD-(IES|IE-S) & \begin{tabular}{|l|} 
Information Technology \\
Laboratory \\
\end{tabular} & $\begin{array}{l}\text { Computational Science } \\
\text { and Engineering Division }\end{array}$ & Scientific Software Branch \\
\hline CEERD-IEI & $\begin{array}{l}\text { Information Technology } \\
\text { Laboratory }\end{array}$ & $\begin{array}{l}\text { Computational Science } \\
\text { and Engineering Division }\end{array}$ & $\begin{array}{l}\text { Sensors Integration } \\
\text { Branch }\end{array}$ \\
\hline CEERD-IER & \begin{tabular}{|l} 
Information Technology \\
Laboratory
\end{tabular} & $\begin{array}{l}\text { Computational Science } \\
\text { and Engineering Division }\end{array}$ & $\begin{array}{l}\text { Institute for Systems } \\
\text { Engineering Research }\end{array}$ \\
\hline CEERD-IS & $\begin{array}{l}\text { Information Technology } \\
\text { Laboratory }\end{array}$ & $\begin{array}{l}\text { Software Engineering \& } \\
\text { Informatics Division }\end{array}$ & \\
\hline CEERD-(ISS|IS-S) & $\begin{array}{l}\text { Information Technology } \\
\text { Laboratory }\end{array}$ & $\begin{array}{l}\text { Software Engineering \& } \\
\text { Informatics Division }\end{array}$ & $\begin{array}{l}\text { Software Engineering \& } \\
\text { Evaluation Branch }\end{array}$ \\
\hline CEERD-ISK & $\begin{array}{l}\text { Information Technology } \\
\text { Laboratory }\end{array}$ & $\begin{array}{l}\text { Software Engineering \& } \\
\text { Informatics Division }\end{array}$ & $\begin{array}{l}\text { Information Science \& } \\
\text { Knowledge MGMT Branch }\end{array}$ \\
\hline CEERD-(IST|ISC) & $\begin{array}{l}\text { Information Technology } \\
\text { Laboratory }\end{array}$ & $\begin{array}{l}\text { Software Engineering \& } \\
\text { Informatics Division }\end{array}$ & $\begin{array}{l}\text { CAD/BIM Technology } \\
\text { Center }\end{array}$ \\
\hline CEERD-(ISE|ISG) & \begin{tabular}{|l|} 
Information Technology \\
Laboratory \\
\end{tabular} & \begin{tabular}{|l} 
Software Engineering \& \\
Informatics Division
\end{tabular} & $\begin{array}{l}\text { Cybersecurity Engineering } \\
\text { \& Analysis Branch }\end{array}$ \\
\hline CEERD-IH & $\begin{array}{l}\text { Information Technology } \\
\text { Laboratory } \\
\end{array}$ & $\begin{array}{l}\text { Supercomputing } \\
\text { Research Center }\end{array}$ & \\
\hline CEERD-IHP & $\begin{array}{l}\text { Information Technology } \\
\text { Laboratory }\end{array}$ & $\begin{array}{l}\text { Supercomputing } \\
\text { Research Center }\end{array}$ & ERDC HPC Center \\
\hline CEERD-IHS & $\begin{array}{l}\text { Information Technology } \\
\text { Laboratory }\end{array}$ & $\begin{array}{l}\text { Supercomputing } \\
\text { Research Center }\end{array}$ & ERDC DSRC \\
\hline CEERD-(IHD|IH-D) & $\begin{array}{l}\text { Information Technology } \\
\text { Laboratory }\end{array}$ & $\begin{array}{l}\text { Supercomputing } \\
\text { Research Center }\end{array}$ & HPC Data Science Center \\
\hline CEERD-TZ & $\begin{array}{l}\text { Geospatial Research } \\
\text { Laboratory }\end{array}$ & & \\
\hline CEERD-TZA & $\begin{array}{l}\text { Geospatial Research } \\
\text { Laboratory }\end{array}$ & Office of Director & \\
\hline
\end{tabular}




\begin{tabular}{|c|c|c|c|}
\hline Office code & Office 1 & Office 2 & Office 3 \\
\hline CEERD-TZB & $\begin{array}{l}\text { Geospatial Research } \\
\text { Laboratory }\end{array}$ & Office of Deputy Director & \\
\hline CEERD-(TZT|TZ-T) & $\begin{array}{l}\text { Geospatial Research } \\
\text { Laboratory }\end{array}$ & $\begin{array}{l}\text { Office of Technical } \\
\text { Directors }\end{array}$ & \\
\hline CEERD-(TZM|TZ-M) & $\begin{array}{l}\text { Geospatial Research } \\
\text { Laboratory }\end{array}$ & $\begin{array}{l}\text { Management Integration } \\
\text { Office }\end{array}$ & \\
\hline CEERD-(TR|TS) & $\begin{array}{l}\text { Geospatial Research } \\
\text { Laboratory }\end{array}$ & $\begin{array}{l}\text { Topography, Imagery \& } \\
\text { Geospatial Research } \\
\text { Division }\end{array}$ & \\
\hline CEERD-(TRR|TR-R) & $\begin{array}{l}\text { Geospatial Research } \\
\text { Laboratory }\end{array}$ & $\begin{array}{l}\text { Topography, Imagery \& } \\
\text { Geospatial Research } \\
\text { Division }\end{array}$ & $\begin{array}{l}\text { Data Representation } \\
\text { Branch }\end{array}$ \\
\hline CEERD-(TRA|TR-A) & $\begin{array}{l}\text { Geospatial Research } \\
\text { Laboratory }\end{array}$ & $\begin{array}{l}\text { Topography, Imagery \& } \\
\text { Geospatial Research } \\
\text { Division }\end{array}$ & $\begin{array}{l}\text { Geospatial Applications } \\
\text { Branch }\end{array}$ \\
\hline CEERD-(TRS|TR-S) & $\begin{array}{l}\text { Geospatial Research } \\
\text { Laboratory }\end{array}$ & $\begin{array}{l}\text { Topography, Imagery \& } \\
\text { Geospatial Research } \\
\text { Division }\end{array}$ & $\begin{array}{l}\text { Data \& Signature Analysis } \\
\text { Branch }\end{array}$ \\
\hline CEERD-(TRG|TR-G) & $\begin{array}{l}\text { Geospatial Research } \\
\text { Laboratory }\end{array}$ & $\begin{array}{l}\text { Topography, Imagery \& } \\
\text { Geospatial Research } \\
\text { Division }\end{array}$ & $\begin{array}{l}\text { Information Generation \& } \\
\text { Management Branch }\end{array}$ \\
\hline CEERD-TS-F & $\begin{array}{l}\text { Geospatial Research } \\
\text { Laboratory }\end{array}$ & $\begin{array}{l}\text { Topography, Imagery \& } \\
\text { Geospatial Research } \\
\text { Division }\end{array}$ & Force Projection Branch \\
\hline
\end{tabular}




\section{Acronyms and Abbreviations}

$\begin{array}{ll}\text { ACE-IT } & \text { Army Corps of Engineers Information Technology } \\ \text { CAC } & \text { Common Access Card } \\ \text { CMS } & \text { Content Management System } \\ \text { DoD } & \text { Department of Defense } \\ \text { ERDC } & \text { Engineer Research and Development Center } \\ \text { IP } & \text { Internet Protocol } \\ \text { ITL } & \text { Information Technology Laboratory } \\ \text { ORTT } & \text { Office of Research and Technology Transfer } \\ \text { PIN } & \text { Personal Identification Number } \\ \text { RDE } & \text { Research and Development Environment } \\ \text { SSO } & \text { Single Sign On } \\ \text { URL } & \text { Uniform Resource Locator }\end{array}$




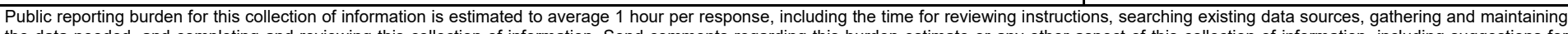

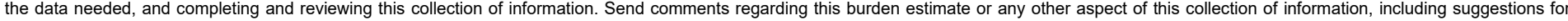

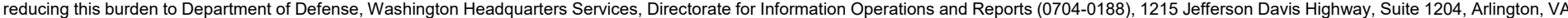

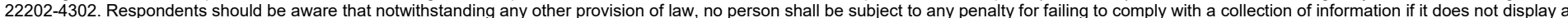
currently valid OMB control number. PLEASE DO NOT RETURN YOUR FORM TO THE ABOVE ADDRESS.
1. REPORT DATE (DD-MM-YYYY)
September 2020

\section{REPORT TYPE}
Final

4. TITLE AND SUBTITLE

Discover ERDC Support Staff User's Guide

3. DATES COVERED (From - To)

5a. CONTRACT NUMBER

5b. GRANT NUMBER

5c. PROGRAM ELEMENT NUMBER

5d. PROJECT NUMBER

5e. TASK NUMBER

5f. WORK UNIT NUMBER

8. PERFORMING ORGANIZATION REPORT NUMBER

ERDC/ITL SR-20-17

Information Technology Laboratory

U.S. Army Engineer Research and Development Center

3909 Halls Ferry Road

Vicksburg, MS 39180-6199

9. SPONSORING / MONITORING AGENCY NAME(S) AND ADDRESS(ES)

10. SPONSOR/MONITOR'S ACRONYM(S)

ERDC Office of Research and Technology Transfer (ORTT)

3909 Halls Ferry Road

Vicksburg, MS 39180-6199

11. SPONSOR/MONITOR'S REPORT

NUMBER(S)

\section{DISTRIBUTION / AVAILABILITY STATEMENT}

Approved for public release; distribution is unlimited.

\section{SUPPLEMENTARY NOTES}

ERDC Office of Research and Technology Transfer, WIC 19F1H5

\section{ABSTRACT}

Knowledge management plays a vital role for the successful execution of research projects at the U.S. Army Engineer Research and Development Center (ERDC). Accumulating and building upon knowledge is the cornerstone of the research and development process. Maintaining knowledge and providing access to it is essential to the successful execution of research programs. An initiative to improve access to knowledge and tools available to researchers was begun by the Office of Research and Technology Transfer (ORRT). The result of that initiative is a knowledge portal called Discover ERDC.

This document provides a detailed look into how content on the Discover ERDC site is maintained from a Support Staff viewpoint, and how those assigned to manage user accounts can accomplish their duties.

\section{SUBJECT TERMS}

Engineer Research and Development Center (U.S.)--Employees-- Directories

\begin{tabular}{|l|c|c|c|l|l|}
\hline \multicolumn{2}{|l|}{ 16. SECURITY CLASSIFICATION OF: } & $\begin{array}{l}\text { 17. LIMITATION } \\
\text { OF ABSTRACT }\end{array}$ & $\begin{array}{l}\text { 18. NUMBER } \\
\text { OF PAGES }\end{array}$ & $\begin{array}{l}\text { 19a. NAME OF RESPONSIBLE } \\
\text { PERSON }\end{array}$ \\
\cline { 1 - 2 } $\begin{array}{c}\text { a. REPORT } \\
\text { Unclassified }\end{array}$ & $\begin{array}{c}\text { b. ABSTRACT } \\
\text { Unclassified }\end{array}$ & $\begin{array}{c}\text { c. THIS PAGE } \\
\text { Unclassified }\end{array}$ & SAR & 39 & $\begin{array}{l}\text { TeLEPHONE NUMBER (include } \\
\text { area code) }\end{array}$ \\
\end{tabular}

\begin{tabular}{|l|c|c|c|l|l|}
\hline \multicolumn{2}{|l|}{ 16. SECURITY CLASSIFICATION OF: } & $\begin{array}{l}\text { 17. LIMITATION } \\
\text { OF ABSTRACT }\end{array}$ & $\begin{array}{l}\text { 18. NUMBER } \\
\text { OF PAGES }\end{array}$ & $\begin{array}{l}\text { 19a. NAME OF RESPONSIBLE } \\
\text { PERSON }\end{array}$ \\
\cline { 1 - 2 } $\begin{array}{c}\text { a. REPORT } \\
\text { Unclassified }\end{array}$ & $\begin{array}{c}\text { b. ABSTRACT } \\
\text { Unclassified }\end{array}$ & $\begin{array}{c}\text { c. THIS PAGE } \\
\text { Unclassified }\end{array}$ & SAR & 39 & $\begin{array}{l}\text { TeLEPHONE NUMBER (include } \\
\text { area code) }\end{array}$ \\
\end{tabular}

Web applications

Knowledge management 